\title{
Trading Human Rights: How Preferential Trade Agreements Influence Government Repression
}

\author{
Emilie M. Hafner-Burton
}

\begin{abstract}
A growing number of preferential trade agreements (PTAs) have come to play a significant role in governing state compliance with human rights. When they supply hard standards that tie material benefits of integration to compliance with human rights principles, PTAs are more effective than softer human rights agreements (HRAs) in changing repressive behaviors. PTAs improve members' human rights through coercion, by supplying the instruments and resources to change actors' incentives to promote reforms that would not otherwise be implemented. I develop three hypotheses: (1) state commitment to HRAs and (2) PTAs supplying soft human rights standards (not tied to market benefits) do not systematically produce improvement in human rights behaviors, while (3) state commitment to PTAs supplying hard human rights standards does often produce better practices. I draw on several cases to illustrate the processes of influence and test the argument on the experience of 177 states during the period 1972 to 2002.
\end{abstract}

Human rights violations are pervasive. ${ }^{1}$ As a substantial percentage of states repress their citizens, an increasingly dense set of formal treaties, conventions, and protocols have been designed to protect the inalienable rights of human beingshuman rights agreements (HRAs). These agreements are different than other forms of international cooperation designed to overcome collective action problems and to internalize cross-border externalities. HRAs are designed to regulate sov-

I would like to thank Mike Colaresi, Dan Drezner, David Lake, Lisa Martin, Walter Mattli, John Meyer, Mark Pollack, Erik Voeten, Jim Vreeland, and two anonymous reviewers for their detailed and thoughtful comments on various drafts of this manuscript, as well as the many other people who have helped me by asking hard questions along the way. I would also like to thank Michael Barnett, Charles Franklin, and Jon Pevehouse for advice during the dissertation research that supports this article, and Alexander H. Montgomery for assistance in data management. All faults are my own. For generous assistance in the collection of data, I thank the National Science Foundation (SES 2CDZ414 and SES 0135422), John Meyer, and Francisco Ramirez. For support during the writing of the article, I thank Nuffield College at Oxford University, and most importantly, Lynn Eden and Stanford's Center for International Security and Cooperation.

1. Last year, Amnesty International documented human rights abuses in 151 countries and territories. Amnesty International Report 2003. 
ereign governments' behaviors toward individuals, and a great many scholars of international law and politics believe they are a valuable source of domestic policy change, encouraging repressors to change their practices. ${ }^{2}$ In the face of such optimism, however, many scholars are unconvinced. HRAs, scholars remind us, lack the engines of compliance that drive many other areas of international law; they supply no apparent material incentives to conform, and no superior power is authorized to compel observance of the law. ${ }^{3}$ The debate is heated and unresolved.

Yet HRAs are no longer the only alternative for international regulation of domestic human rights policy. Few realize that the governance menu has recently expanded to include a growing number of formal institutions that embed human rights standards ${ }^{4}$ into rules governing market access-preferential trade agreements (PTAs). ${ }^{5}$ PTAs are a rapidly growing class of international institutions that govern market access between member states of an economic region. ${ }^{6}$ Semi-autonomous from the global structure of the World Trade Organization (WTO), ${ }^{7}$ PTAs frequently regulate spheres of social governance that increasingly include human rights standards. Some, such as the Euro-Mediterranean Association Agreements, supply "hard" standards that tie agreement benefits to member compliance with specific human rights principles. Others, such as the West African Economic and Monetary Union, supply "soft" standards that are only vaguely tied to market access and unconditional on member states' actions. ${ }^{8}$

My argument is a simple one about institutional design and influence. In the area of human rights, hard laws are essential: change in repressive behavior almost

2. See Rosati 2001; Lutz and Sikkink 2000; Risse, Ropp, and Sikkink 1999; Koh 1998; and Franck 1988. Hathaway 2002 argues that leading perspectives on international law assume that states intend to comply with their internal legal commitments. This assumption, commonly applied to HRAs, has been widespread among international lawyers and scholars but seldom tested.

3. See Hafner-Burton and Tsutsui 2005; Hathaway 2002; and Donnelly 1986.

4. A standard is an acknowledged behavioral criterion established by authority, custom, or general consent as a model or example. See Merriam-Webster Unabridged online Dictionary, available at 〈http:// www.m-w.com/cgr-bin/dictionary) accessed 6 may 2005.

5. I define PTAs in the broadest sense possible to include preferential trade instruments of many kinds, including unilateral preferential schemes, bilateral and regional agreements, and reciprocal and nonreciprocal agreements.

6. See De Melo and Panagariya 1993; Mansfield 1998; Mattli 1999; and McCall Smith 2000.

7. WTO members participating in PTAs are required to meet a set of preferential trading conditions defined in the text of GATT Article XXIV, Ad Article XXIV, and its updates, which include the 1994 Understanding on the Interpretation of Article XXIV of the General Agreement on Tariffs and Trade, as well as the text of GATS Article V. Note that many PTAs are not notified to the WTO.

8. Abbott and Snidal 2000 identify variation in international legalization: hard laws are legally binding obligations that are precise and that delegate authority for interpreting and implementing the law; while soft laws are those that deviate from hard along several dimensions. The use of hard and soft law through the remainder of this article invokes Abbott and Snidal's attention to variation but simplifies by identifying one primary distinguishing characteristic: conditionality. Hard PTA standards establish enforceable conditions for integration, while soft standards appeal to voluntary principles of cooperation that do not require behavioral change to receive market access benefits. Abbott and Snidal 2000, 421. 
always requires legally binding obligations that are enforceable. ${ }^{9}$ HRAs, on the whole, do not supply adequate enforcement, but there are strong reasons to expect that a growing number of PTAs with hard standards now govern state compliance with international human rights principles, with considerable potential to influence states' behaviors toward citizens. Indeed, these agreements may often be more effective than HRAs in changing the basic conduct of repressive governments toward greater protection for some fundamental rights. Certain PTAs enforce many principles of international law that most HRAs cannot. I offer three hypotheses.

First, most HRAs are not likely to effectively reduce violations most of the time. As I will elaborate in this article, HRAs are principally soft: they influence governments' human rights practices through persuasion rather than coercion, supplying weak obligations. ${ }^{10}$ Persuading repressive actors to change their preferences for behavior requires a supply of convincing argumentation, a long-time horizon, simultaneous targeting of multiple actors, and access to the target abusers. HRAs, unfortunately, do not supply many of these conditions.

Second, PTAs are designed to enforce voluntary commitments to coordinate market policies at a transnational level. PTAs accordingly supply different mechanisms of influence, and they sometimes are designed to influence human rights. As I shall show, when PTAs supply soft human rights standards, they offer no capacity for coercive influence. Like HRAs, these agreements are at best designed to supply weak tools of persuasion and are unlikely to have any strong influence on government repression.

Third, when they implement hard standards, PTAs influence through coercion: they provide member governments with a mandate to protect certain human rights, while they supply the material benefits and institutional structures to reward and punish members' behavior. As I shall show, coercing repressive actors to change their behaviors requires a conditional supply of valuable goods wanted by target repressors. It does not require changing deeply held preferences for human rights and is likely to take place in a shorter time horizon. These agreements accordingly improve members' human rights by supplying the instruments and resources to change repressive actors' incentives to promote policy reforms that would not otherwise be implemented.

In the following sections, I elaborate this incentive-based theory of compliance with the principles of international human rights. At issue is the nature of institutional effects ex post of state membership in agreements that adopt various human

9. This view stands in sharp contrast to the belief that coercion is unnecessary or counterproductive: that governments often conform to global human rights laws out of concern for legitimacy, even when laws are powerless to enforce compliance; and that coercion necessarily produces adverse consequences on the enjoyment of human rights. See Goodman and Jinks 2004; Johnston 2001; Payne 2001; Price 1998; Helfer and Slaughter 1997; Finnemore 1996; Koh 1996-97; Franck 1990; Henkin 1979; as well as Bossuyt 2000. For an exception, see Martin and Sikkink 1993.

10. HRAs, as with PTAs, vary in their degree of institutionalization, and exceptions to this claim are discussed in later sections of the article. 
rights standards, hard and soft. I seek to explain the consequences of PTA membership on states' human right behaviors and not the initial formation of the agreements. ${ }^{11}$ In order to do so, I introduce and analyze new institutional data on PTAs, HRAs, and states' human rights practices. Several cases demonstrate that many PTAs now adopt hard human rights standards and sometimes are effective motivators of reform. Cross-national analyses from 1972 to 2002 provide more systematic evidence that agreements with hard standards can and often do motivate better protection of human rights.

\section{A Matter of Influence: How Institutions Change Governments' Behaviors}

For the better part of the past century, intellectuals from many disciplines argued that international laws are powerless rules that nations seldom obey and that cannot be readily enforced; and that international institutions are not likely themselves to influence the behavior of states. ${ }^{12}$ Today, most scholars of institutions take strong exceptions to these views.

Some scholars view institutions as instruments created to overcome various collective action dilemmas to solve a variety of substantive problems. ${ }^{13}$ In this view, state defection from the rules is an ever present threat motivated by rational calculations of gains from unilateral action. Sustained compliance with institutions that challenge domestic preferences for behavior thus almost always requires some measure of coercion. ${ }^{14}$ The fact that states are regularly observed to comply with international rules without coercive enforcement, scholars argue, is likely an artifact of state selection into institutions that often require only the most modest changes in behavior. ${ }^{15}$ Indeed, international institutions are not always designed to change behavior, and when they are, compliance with the rules usually requires some coercive mechanism of influence to make the costs of defection higher than the costs of conformity.

This view has now come to stand in sharp contrast to the belief that "almost all nations observe almost all principles of international law and almost all of their obligations almost all of the time." ${ }^{16}$ Scholars have elaborated many variations of this argument, establishing that states can be persuaded without coercion to com-

11. I nonetheless address the question of formation in some detail in the pages to come in order to consider the possibility that PTA influence is determined by self-selection.

12. See Austin and Austin 1861; Krauthammer 1989; and Mearsheimer 1994/1995.

13. Martin 1992, 1993.

14. See Axelrod 1984; Keohane 1984; and Yarbrough and Yarbrough 1997.

15. Downs et al. 1996. This finding is nicely articulated in the case of human rights by Moravcsik 1995, who shows that European human rights regimes are likely to have little effect on those states that are not already disposed toward transformation, namely newly developing states.

16. See Henkin 1979; and Koh 1996-97. 
ply with rules that require substantial behavioral changes, often motivated by concerns for legitimacy rather than fear of sanctions. ${ }^{17}$ Scholars of human rights have long recognized that hard rules to enforce human rights are important, yet a great many make the case that, in the absence of enforcement, even soft international laws can influence domestic policy. ${ }^{18}$ In this view, international human rights regimes influence states' behaviors by providing rules and organizational structures to determine the appropriate constraints on national sovereignty in a given issue-area. These regimes also provide the justification and forum for action that can shape states' political interests and beliefs about appropriate actions. ${ }^{19}$ States are thus actively encouraged to obey international laws through a continual and interactive process of rationalization and communication: through persuasion toward belief change. ${ }^{20}$ When state actors defect from the rules, their behavior is frequently motivated by domestic bureaucratic failure, shaped by the vagueness and indeterminacy of treaty law, the restricted capacity of the states themselves, or unmanageable social or economic changes taking place inside the nation. ${ }^{21}$ Others go so far as to argue that coercion is often ineffective and at times counterproductive. ${ }^{22}$

This debate over institutional influence is at the foundation of the argument proposed here. As I argue, trade agreements are designed to solve a different set of problems than human rights agreements and supply different properties of influence. PTAs with hard standards can be more effective in influencing compliance with human rights principles than most HRAs; when PTAs supply coercive mechanisms of influence that HRAs lack, they tie compliance to substantial market benefits. Consider the logic of the argument in stages.

\section{The Problem of Human Rights Compliance}

The problem of human rights compliance (see Figure 1) ${ }^{23}$ is that many sovereign governments domestically abuse a set of principled ideas proffered internationally through global laws and networks of advocates. This behavior is almost always caused by purposeful disobedience by actors who choose defection from the rules.

17. See Kratochwil 1989; Franck 1995; Finnemore 1996; and Meyer et al. 1997.

18. See note 9 .

19. For the general argument, see Chayes and Chayes 1990, 1993, and 1998. For applications to human rights, see Goodman and Jinks 2004; Koh 1996-97; Franck 1990; and Henkin 1979. For applications to environmental policy, see Mitchell 1993; and Young 1994.

20. See Goodman and Jinks 2004; Bulterman and Kuijer 1996; Petersmann 1997; and Price 1998.

21. Chayes and Chayes 1998.

22. Human rights critics of economic sanctions, for example, contend that sanctions often fail to produce human rights compliance and, worse, cause further violations. See Rai and Eden 2001; and Helson and DeVecchi 2000.

23. Figure 1 describes the percentage of all states in the world system reported to employ repressionthrough acts of political terror or by violating civil liberties-and that have ratified either the Convention on Torture or the International Covenant on Civil and Political Rights. All data are described in detail in the pages to follow. 


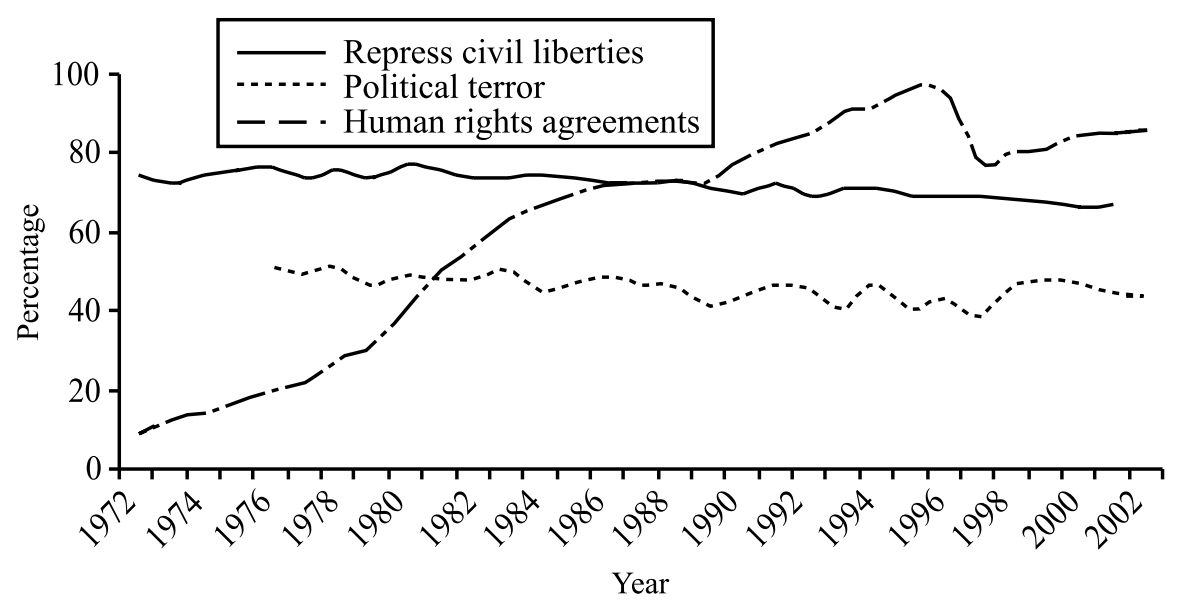

FIGURE 1. Human rights behaviors: Percentage of states that repress and that ratify human rights agreements

Noncompliance in the area of human rights-especially for the most egregious violations - can rarely be explained by bureaucratic failure. Human rights laws are not vague about prohibitions on torture or indiscriminate killing, and difficult social or economic changes take place inside states that do not repress their citizens. Human rights violations are by and large calculated acts taken by different actors that expect some form of gains from repression.

A powerful constituency of states and advocates around the world hold strong and well-articulated preferences to make all states accountable for violations. They seek to influence repressive governments' behaviors to become compliant with rules protecting the inalienable rights of all people. International agreements governing human rights are accordingly charged with the difficult task of changing repressive governments' behaviors inside the sovereign territory of the state. ${ }^{24}$ There are two principal kinds of violators they must address.

First, elites working in some repressive governments may hold preferences for human rights that they cannot self-enforce at home. This problem is perhaps most common to newly established democracies, where recently elected leaders are likely to have strong interests in consolidating human rights, while at the same time face substantial domestic opposition toward implementation, now and into the future. ${ }^{25}$ Second, other repressive governments may be ruled by decision makers with no identifiable incentives for human rights, or with strong incentives for repression. The vast literatures on repression suggest that elites ruling autocratic governments often gain substantial political and economic benefits from tyranny-benefits that 
range from a strong hold on political power to substantial economic wealth. ${ }^{26}$ Elites facing political competition by armed insurgent groups are also among the most likely to hold strong incentives for occasional to systematic use of repression to maintain political control, which is a highly valued good.

If the problem to be solved is to sway an assortment of repressors to conform to international principles of human rights laws, the solution is to design international institutions with the capacity to influence elites operating under different domestic political situations to transform their behaviors.

\section{Mechanisms of Influence}

It is well established in the theoretical literatures that international institutions can influence governments' human rights actions through two principal mechanisms: coercion and persuasion. As I have noted above, scholars of international organization and law disagree strongly about which form of influence should be the most effective. Although the majority of human rights scholars believe that coercion may be a useful tool of domestic policy influence, many remain optimistic that international institutions lacking coercive authority can nonetheless bring about compliance with law. I now turn to consider both mechanisms more carefully as they apply to human rights.

Persuasion is "the active, often strategic, inculcation of norms." ${ }^{27}$ When they persuade, international institutions actively influence human rights by supplying targeted information to convince or teach repressive actors new ideas that are more consistent with the principles of international laws. ${ }^{28}$ Persuasion is a process of changing actors' preferences and understandings of appropriate social behavior to create new social facts. ${ }^{29}$ As a process, it works over time, changing beliefs about legitimate behavior through many stages of diffusion and internalization. ${ }^{30}$ In this sense, a government has been persuaded when its decision-making elites have replaced a previous set of beliefs about human rights with a new set of principled ideas.

Coercion is "the threat or act by a sender government or governments to disrupt economic exchange with the target state, unless the target acquiesces to the articulated demand." ${ }^{31}$ When they coerce, institutions can influence target governments' repressive behaviors by increasing the rewards of compliance or the costs of defection through material rewards and punishments. ${ }^{32}$ Coercion influences

26. See Kirkpatrick 1979; Howard and Donnelly 1986; Mitchell and McCormick 1988; and Henderson 1991.

27. Goodman and Jinks 2004, 10.

28. Finnemore 1996.

29. See Ruggie 1998; and Payne 2001.

30. See Finnemore and Sikkink 1998; and Risse, Ropp, and Sikkink 1999.

31. Drezner 2003, 643.

32. See Goodman and Jinks 2004; and Downs et al. 1996. 
human rights behavior by changing actors' calculations of the price of adopting certain behaviors over others. Unlike persuasion, an actor can be coerced to comply with basic principles of human rights law and simultaneously hold preferences for repression, if the benefits of compliance are perceived to outweigh the costs. Moreover, coercion can influence human rights behaviors short of implementation. As the literatures on economic bargaining suggest, effective cases of coercion are often likely to end with threat of punishment rather than implementation. Compliance before sanction avoids the costs associated with sanctioning for both target and sender and is thus more efficient. ${ }^{33}$ Threat is often enough. ${ }^{34}$

\section{Influencing Compliance}

There are four main reasons to expect that persuasion, alone, is unlikely to provide strong incentives to change most repressive actors' behaviors. First, persuasion requires changing actors' preferences for repression, and these preferences are likely to be highly valued. Repression is often used as a strategy to gain or maintain political power or to accumulate wealth or redistribute resources. In 2003 alone, Amnesty International documented dozens of instances where ruling elites employed acts of terror to maintain power and suppress opposition, including targeted killings of political challengers and terrorizing voters. Repressive opponents, such as armed insurgent groups, competing elites, or low-ranking members of the civil or military services, are also documented to use repression, extracting concessions and side payments from a wide range of targeted populations. ${ }^{35}$ In both cases, the gains from repression were likely to be highly valued and to be strongly preferred by the repressors. Strongly held preferences are likely to be harder to change than weakly held preferences.

Second, when persuasion occurs it is likely to be a slow acting form of influence, taking place over a long-time horizon. To persuade, an institution must mobilize informed advocates to convince repressive actors that their currently held beliefs and habits are no longer appropriate. However, beliefs rarely change over night, but are often sticky. This "perseverance effect" has been confirmed in a wide variety of settings: individuals frequently adhere strongly to their beliefs even after new and better information has been presented. ${ }^{36}$ Moreover, when belief change does take place, it often happens in stages, as individuals pass through intermedi-

33. See Drezner 2003; and Eaton and Engers 1999.

34. The Organization for Economic Cooperation and Development (OECD) concludes, for example, that the Generalized System of Preferences review process creates an independent and strong incentive for improving labor rights conditioned by the agreement, short of the imposition of sanctions. Recipient states have an economic stake in receiving a positive review, both to avoid sanctions, but also to encourage potential investment. See OECD 1996; and Cleveland 2001b.

35. Amnesty International Report 2003.

36. See Anderson 1989; and Slusher and Anderson 1996. 
ate periods of acceptance and rejection of new information. ${ }^{37}$ Persuasion takes time.

Third, persuaded actors may not be consistent across time. New leaders may come to power, and new opponent groups may form with preferences for repression. Successful persuasion of a government thus requires that each new repressive actor is persuaded to change their beliefs about the appropriateness of their behavior. Few repressive governments, however, are ruled consistently by the same elite or face the same set of repressive opponents for periods that are long enough to enact and achieve strong belief change. Leaders of repressive states are regularly overthrown or voted out of power, while domestic human rights opponents come and go.

Finally, persuasion requires repeated access to target repressors. Some repressive actors may be intimately involved in the decision-making processes of international institutions designed to influence human rights. Chief executives or their cabinet members and staff are among the most likely to participate in the repeated interactions organized through international institutions. Other repressive actors, however, are likely to be marginalized from participation in these institutions and remain isolated from active processes of norm inculcation. Armed insurgent groups contesting the government or vigilante civilians targeting ethnic minorities, for example, are not apt to be represented at the United Nations (UN) or to participate in the decision-making processes of most institutions.

Contrary to the belief that institutions can best influence without coercion, there are several reasons to expect that coercion is likely to provide stronger incentives against repression than persuasion under some conditions, and that coercion and persuasion may effectively influence human rights when they are supplied together. First, coercion is likely to be more effective than persuasion (alone) because it does not require changing actors' deeply held preferences for repression, but rather increases the costs of employing repression and the gains of adopting better human rights practices. A coerced actor can simultaneously hold preferences for human rights and choose to curb repressive behaviors in exchange for other forms of gains from international cooperation. They are likely to do so when those gains are more valuable than the benefits of repression. Reforms can be a side payment.

Second, coercion can take place in a much shorter time horizon than persuasion. If an institution supplies valuable goods under the condition that targeted repressors make human rights policy changes now or in the short term future, repressors are more likely to react in the short term to adopt new practices. Immanent sanctions on valuable goods provide strong incentives for reforms in the present rather than repressive behavior into the future.

Third, coercion can change a variety of different repressive actors' behaviors when they value the gains of cooperation more than the gains of repression. In fact, any domestic opponent to human rights with strong preferences for the goods

37. See Risse, Ropp, and Sikkink 1999; and Schwitzgebel 1999. 
achieved through cooperation can, under certain conditions, be coerced into supporting human rights reforms they would not otherwise select. ${ }^{38}$ Moreover, coercive instruments that successfully institutionalize new benefits can influence the preferences of future leaders with incentives for repression. In principle, these instruments can do so under the condition that institutionalization of the coercive instrument has led to new gains, now perceived to be valuable by the incoming government, that are greater than existing incentives to use repression. ${ }^{39}$

Fourth, coercion does not require direct and repeated access to target repressors. It only requires that target actors are informed of the coercion trade-off and value the benefits of international cooperation more than they value the gains from repression. No repeated institutional contact between the actors governing international institutions and the repressors they are trying to influence is, in principle, necessary. In practices, coercion and persuasion may take place simultaneously and are often compatible processes of influence.

\section{A Matter of Design: How HRAs and PTAs Change Governments' Behaviors}

In the preceding section, I have argued that the problem of human rights compliance is to influence repressive governments' domestic behaviors and that international institutions can influence human rights through two mechanisms. Although many scholars are optimistic that HRAs lacking hard standards are still capable of substantial influence on domestic policy, I argue the contrary: coercion is much more likely than persuasion (alone) to be effective. In the following section, I apply these claims to HRAs and PTAs, respectively, and develop three positive expectations about influencing human rights behaviors.

\section{Human Rights Agreements}

The international human rights regime is championed by a growing number of treaties and instruments designed to protect identifiable groups, such as women and children, as well as to protect all people against particular government behaviors, such as torture. At the heart of this regime are the UN Charter (Article 55) and seven international agreements that define a set of global regulations. Almost all states in the world have ratified one or more of these instruments.

38. These conditions require that benefits gained from adopting unwanted reforms are greater than costs of adoption; that no credible alternative supply of the goods are available without human rights conditions; and that target actors hold incentives for the goods achieved through integration. Also see Moravcsik 2000 for a similar argument in the European context.

39. For a discussion of hand tying through credible commitment, see Martin 1998 and 2000; Abbott and Snidal 2001; and Kahler and Lake 2003. I would like to thank an anonymous reviewers for helping me to clarify this point. 
This architecture of international law was principally constructed to influence through persuasion: to identify and classify which rights are globally legitimate, to provide a forum for the exchange of information regarding violations, and to sway governments and violators that laws protecting human rights are appropriate constraints on the nation-state that should be respected. Over the years, the regime has proven increasingly competent in supplying the instruments necessary to collect and exchange information on human rights violations, and to disseminate that information on a global scale. ${ }^{40}$

Despite this substantial capacity to classify and disseminate human rights norms and establish monitoring institutions, most agreements were not designed to influence through coercion, and those that were often fail to be effective: they remain quite soft. ${ }^{41}$ Most HRAs supply no formal enforcement mechanisms ${ }^{42}$ to provide or disrupt valuable exchange with a target state. ${ }^{43}$ They offer no material rewards in exchange for better practices, and they cannot directly punish violators by withholding valuable goods. ${ }^{44}$ At their best, most HRAs influence by mobilizing human rights advocates and supplying repressors with information and legitimating motivations to internalize new norms of appropriate behavior.

There are therefore good reasons to be skeptical that most HRAs directly or frequently persuade repressive actors to change their human rights behaviors, especially among those who value repression highly. HRA's supply strong tools of moral suasion but offer few valuable incentives for repressors to change their beliefs about appropriate behaviors. They identify and lobby target individuals and groups, but they are often limited to accessing repressors that consent to be targeted to

40. The major treaties furnish UN committees that formally provide a reporting and oversight function.

41. There is today only one major exception to this claim: the European human rights system supplies a unique set of instruments to enforce the Council of Europe's commitment to uphold HRAs. Almost all members have adopted the Convention for the Protection of Human Rights and Fundamental Freedoms into national law, obligating national courts to enforce the agreement's provisions. The European Court of Human Rights is the superior arbitrator of disputes concerning noncompliance with human rights standards under the Convention, acting as a subsidiary to national enforcement in cases of failure. Europe, however, is exceptional. The vast majority of HRAs provide softer standards that are voluntary and weakly enforceable at best. See Cleveland 2001b. The Organization of American States (OAS) offers the closest comparison. The Commission monitors observance of treaty obligations for all states committed to the American Convention on Human Rights, while the Court monitors compliance under the Convention for states that have also recognized the compulsory jurisdiction of the Court. Yet OAS political bodies routinely fail to support or enforce the recommendations of the Commission or the judgments of the Court, and human rights standards remain effectively soft. See Dulitzky 1999; and Davidson 1997.

42. Small steps toward legal enforcement have only recently begun at the global level through the formation of the International Criminal Court (ICC), as well as at the regional level through courts such as the European and Inter-American Courts of Human Rights, and the state level through the two International Criminal Tribunals in the Former Yugoslavia and Rwanda. These institutions signal an important step toward management of human rights, but they nevertheless remain extremely limited in their jurisdiction and in their effectiveness to provide repressive states with the incentives to protect human rights.

43. See Cottier 2002; and Goodman and Jinks 2004.

44. Donnelly 1986. 
receive information. The exchange of information, once it begins, usually takes place over many months, if not years, and repressive actors inside the targeted state may well have changed during this time. What is more, there is no single HRA effectively able to punish perpetrators of even the most egregious violations of human rights. ${ }^{45}$

The best case study evidence to date supports the argument. Risse and colleagues show that influence through persuasion depends crucially on the establishment of sustainable networks of advocates among domestic and transnational actors; that persuasion happens through several stages over time; and that the inculcation of new norms among the worst abusers often requires some coercive processes of instrumental bargaining, at least in the beginning. ${ }^{46}$ Because repressors value the gains from repression highly, they often use repressive acts to effectively outlaw or restrict domestic human rights mobilization.

All told, HRAs rarely create the conditions necessary for state compliance with human rights because they are soft: persuasion, alone, is a weak mechanism of influence that does not supply strong enough incentives or commitment instruments to outweigh defection.

H1: State commitment to HRAs does not systematically produce improvement in human rights behaviors after commitment. ${ }^{47}$

\section{Preferential Trade Agreements}

Trade liberalization is today regulated by multilateral institutions. At the heart of this system of liberalization is the 1947 General Agreement on Trade and Tariffs (GATT) and the WTO. This movement toward the globalization of trade has taken place in the context of regionalism, as a growing number of states commit to regulate trade through preferential agreements. ${ }^{48}$ These institutions establish macroeconomic measures that prohibit or restrict access to national markets of products and services imported from other partners, and they prescribe legitimate trade actions and decision-making procedures that states should take to comply with their commitments. PTAs exist alongside the WTO agreements and their prescriptions for the liberalization of trade in goods and services are organized vertically, so that states achieve market liberalization at the national level, voluntarily.

PTAs were not principally designed to solve problems of human rights compliance. They are designed to resolve collective action dilemmas and internalize exter-

45. See Cleveland 2001a and 2001b.

46. Risse, Ropp, and Sikkink 1999.

47. It follows from the logic of the argument that the European case is a unique exception to the rule. Because various European human rights instruments provide harder standards than most HRAs, we should expect commitment to these instruments to produce more compliant behavior.

48. For a discussion of the relationship between the world trade system and preferential trade, see Frankel, Stein, and Wei 1996; and Winters 1996. For a discussion of preferential trade statistics at the world level, see Grether and Olarreaga 1998. 
nalities that cross state borders. The instruments of preferential trade chiefly influence through coercion: they coordinate mutually beneficial rules of market access between states and limit defection through threats or acts to disrupt exchange with violating members. Not all PTAs are likely to supply the same degree of credible coercion; some may provide more valuable benefits and greater willingness to enforce the rules than others. All PTAs are nevertheless likely to supply some degree of valuable economic incentives (and thus the potential to change repressors' incentives to support human rights through threat to withdraw goods). Many supply mechanisms of persuasion coupled with coercion.

A growing number of PTAs provide member governments with a mandate to observe human rights (see Figure 2). These agreements fall into two main categories. In the first category are a great many PTAs that provide member governments with soft standards to manage their policy commitments (that is, agreement benefits are unconditional on member states' actions). PTAs do so by incorporating human rights principles and language into the trade contract, "affirming," "recognizing," or "declaring" member states' commitments to various human rights principles in the preamble of the contracts, or making reference to specific international human rights laws. The benefits of integration, however, are not conditional on the observation of these principles.

An example is useful, and there are many from which to choose. Article 6 of the Common Market for Eastern and Southern Africa (COMESA) Treaty articulates the "recognition, promotion and protection of human and people's rights in accordance with the provisions of the African Charter on Human and Peoples' Rights; accountability, economic justice and popular participation in develop-

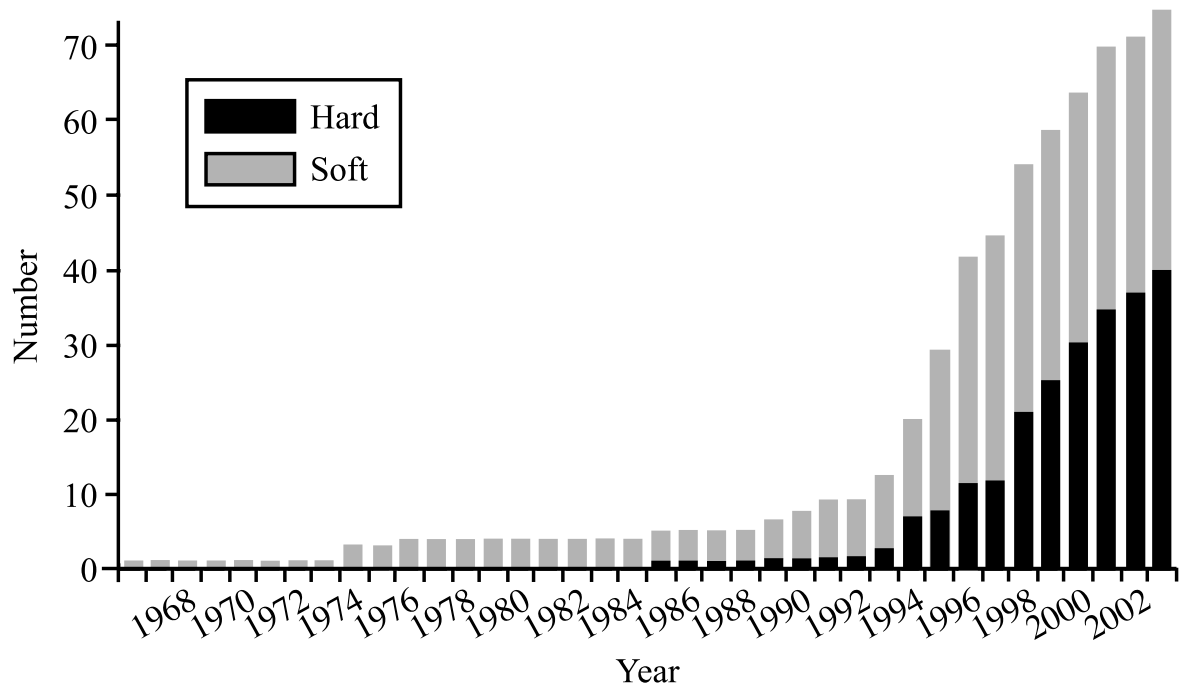

FIGURE 2. Preferential trade agreements with human rights standards 
ment; [and] the recognition and observance of the rule of law" 49 These principles are soft because the agreement provides no active mechanism to sanction or to threaten sanctions against COMESA members that do not respect these rights. Indeed, recent acts of terror in member state Zimbabwe have been formally unobserved by the agreement.

These agreements supply similar human rights influence properties as most HRAs: a set of principled ideas legitimating appropriate and accepted behavior among a community of states. Because the standards are soft-agreement benefits are unconditional on human rights behaviors-this class of institution supplies no coercive mechanisms of influence. If these organizations influence human rights at all, they influence through persuasion, and one should now expect that they are unlikely to change most repressors human rights beliefs or practices.

H2: State commitment to PTAs supplying soft human rights standards does not systematically produce improvement in human rights behaviors after commitment.

Other PTAs provide member governments with "harder" institutional channels to manage and enforce their policy commitments (that is, benefits that are in some way conditional on member states' actions). These PTAs do so by placing the language of human rights in an enforceable incentive structure designed to provide members with the economic and political benefits of various forms of market access. These benefits are supplied under conditions of compliance with the protection of human rights principles or laws identified in the agreement. Behavioral change is a side payment for market gains, enforced through threat (direct or tacit) to disrupt integration or exchange unless a trade partner complies with their human rights commitments specified in the contract. A list of PTAs offering standards, hard or soft, is available in the Appendix 1.

The Lomé and Cotonou Agreements are strong examples of these types of PTAs. Cotonou provides the new institutional structure for the European Community's (EC) largest financial and political framework for cooperation, offering nonreciprocal trade benefits for certain African, Caribbean, and Pacific (ACP) states, including nearly unlimited entry to the EC market for a wide range of goods. The agreement, which replaced successive Lomé Agreements, commits "Parties [to] undertake to promote and protect all fundamental freedoms and human rights, be they civil and political, or economic, social and cultural" ${ }^{50}$ These principles are supported through a political dialogue designed to share information, to cultivate mutual understanding, and to facilitate the formation of shared priorities, including those concerning the respect for human rights (Article 8). Obligations are binding on recipients. They are supported by a review mechanism established in the consultation procedures of Article 96, which require habitual assessments of national

49. Article 6 (d), (e), (f), and (g).

50. Articles 9, 13, and 26. 
developments concerning human rights. ${ }^{51}$ Alongside the agreement are conditional financial protocols allocating resources available to eligible countries through the European Development Fund (EDF). When members are perceived to violate agreement terms, a variety of different actions can be taken to influence behavior. These include the threat or act of withdrawal of membership or financial protocols, as well as the enforcement of economic or political sanctions. Cotonou thus supplies strong elements of both coercion and persuasion.

This second category of agreement supplies coercion mechanisms of influence that most HRAs and all soft PTAs cannot supply. PTAs with hard standards can, under certain conditions, influence through coercion by changing repressive actors' costs and benefits of actualizing their preferences for repression. Consider again the abusive elite with strong preferences for repression. Where persuasion alone is likely to fail, hard standards can influence the problem of compliance without changing actors' preferences. They provide an economic motivation to promote human rights policy reforms that would not otherwise be implemented, and they do so in a relatively short time horizon. When institutionalized PTAs create new and valuable gains, hard agreements can also commit future elites with preferences for liberalization to human rights reforms they would not otherwise select. While influence through persuasion requires leveling a campaign to change a new leader's preferences for repression, influence through coercion requires only that the leader value the gains of integration more than the gains of repression. PTAs, moreover, may increase the costs of repression for any domestic actors that favor liberalization.

Hard PTAs are not a panacea for repression. They are likely to be much less effective in influencing armed opposition groups or governments under insurrection, where preferences for liberalization are low or absent among opponents. To be sure, not all leaders are likely to be influence by all agreements. Severely repressive elites that reap extensive benefits from repression that they value more than integration are apt to defect from agreements that offer only small gains or that require large-scale political upheaval. Moreover, target repressors that can secure an alternative supply of the goods achieved through cooperation without conditionality are likely to reject membership in PTAs that require human rights reforms. Exclusive of these conditions:

H3: State commitment to PTAs supplying hard human rights standards does systematically produce improvement in human rights behaviors after commitment.

\section{Experience and Practice: Cases of PTA Influence}

The expectation that hard PTAs can influence repressive states to change their behaviors is open to the charge of endogeneity. It may well be the case that only 


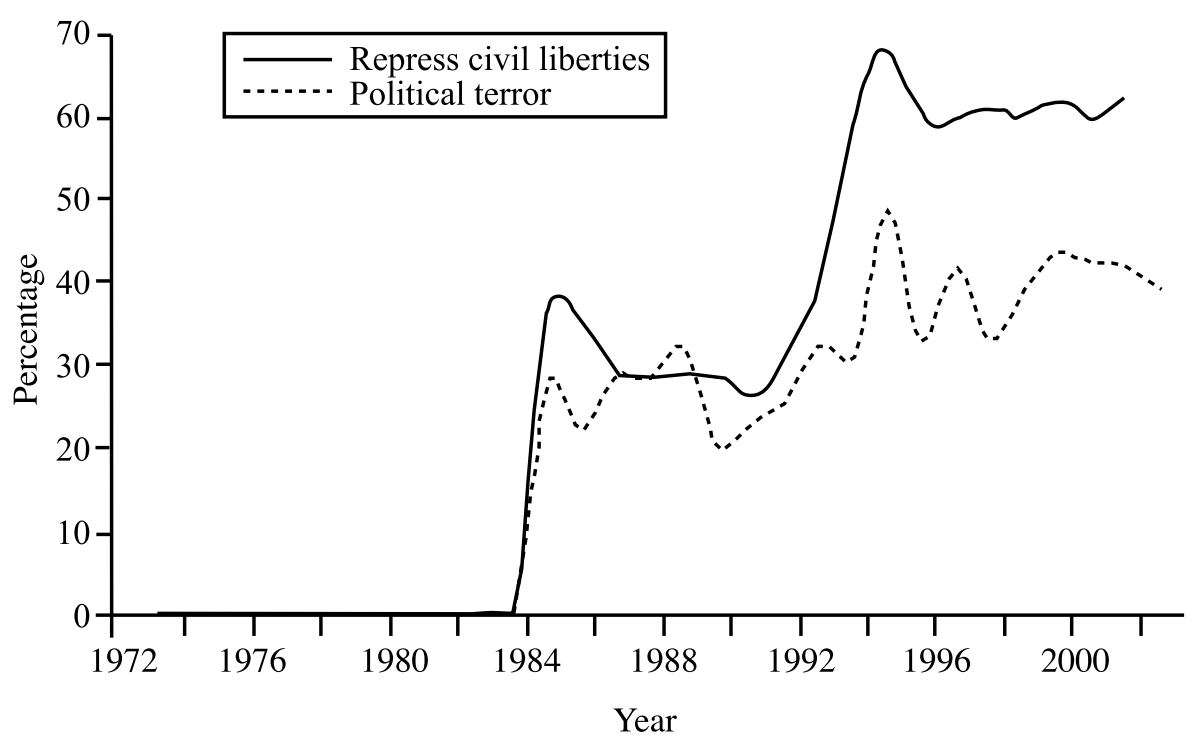

FIGURE 3. Membership in preferential trade agreements standards: Percent repressive

states that protect human rights or that hold preferences to improve their human rights practices will join these agreements in the first place. It is thus crucial to establish whether states only join those PTAs that are consistent with their status quo behaviors. Do repressive states become members of hard PTAs, and how do these agreements influence them to change behavior after joining?

\section{Membership}

States increasingly create and join hard PTAs, and for the past twenty years, repressive governments have been among their many members. In 2002 nearly 30 percent of all states in the international system belonged to a hard agreement of some kind. Figure 3 shows that 40 percent of all agreement members were reported by Amnesty International to employ frequent acts of repression-political imprisonment, execution and other forms of political murder, detention without trial, and other acts of terror. Sixty percent of all members were reported by Freedom House to repress civil liberties. In both cases, the percentage of repressive members has grown substantially over time. ${ }^{52}$ 
Hafner-Burton ${ }^{53}$ has studied the selection process for hard agreements more systematically, controlling for domestic political institutions, economic development, and social movement mobilization across the period 1976 to 2002. Multivariate analyses of membership selection show that repressors are no more or less likely than protectors to select agreements with hard standard. Violators join these agreements almost as often as protectors. Rather, selection is driven strongly by level of institutionalized democracy and economic development. Poor democratizing states in need of economic resource are most likely to select hard agreements. These states are often but not always repressive. Moreover, there is no systematic difference between repressive states' selection of hard compared to soft standards.

\section{Influence}

There is strong evidence that PTAs have influenced their repressive members' human rights behaviors by direct coercion-where contract obligations have been ceased with a target abuser, a set of demands for policy change have been issued, and new behaviors have consequently been adopted. ${ }^{54}$ A refugee massacre in Rwanda after the genocide is one such case.

Rwanda was a nonreciprocal trade member of the EC under the Lomé IV Treaty, which contained a human rights clause guaranteeing member commitment toward the improvement of basic human rights as a fundamental condition of market access. ${ }^{55}$ In reaction to the genocide in 1994, the EC halted Lomé benefits to the Rwandan government. ${ }^{56}$ Although the agreement was in no way equipped to address the causes of genocide and remained inactive during the period of extreme violence, it became influential only in the postgenocide period. Lomé earmarked 22 million ECU for reconstruction under conditions that the new government respect basic human rights and operate under rule of law. ${ }^{57}$

Before the first transfer of resources could take place, the Rwandan army evacuated a refugee camp, violating the rights of many people. In direct reaction, the Commission suspended payment and EC ministers appealed to the Rwandan government to investigate the massacre and to arrest and detain the perpetrators as a precondition for payment. Resistance by the government to impose sanctions on

53. Hafner-Burton 2004.

54. See Fierro 2003; and Hazelzet 2004 for detailed examples in the European context, as well as European Council 2003.

55. There have been at least eleven cases of active suspension of benefits supplied by the EC agreements with the ACP since 1996 alone.

56. EC action in the Rwandan case was challenged by unilateral action on the part of the French government, which chose to circumvent the financial sanctions at the Community level by continuing to supply the Rwandan government with aid. See King 1999.

57. The EU-Rwandan relationship entered into its third phase in 2000 with the 8th EDF, transitioning from rehabilitation to long-term development with more than 20 million Euros allocated for projects supporting good governance and justice. See the EC's Development available at /http://europa.eu.int/ comm/development//. Accessed 10 March 2005. 
members of the army led to the unconditional withholding of funds until sanctions were implemented. In 1995 the government agreed to prosecute those responsible, and the Commission conditionally reinstated payments under Lomé. ${ }^{58}$ Influence was direct and actively coercive..$^{59}$

In two similar cases, human rights reforms were initiated in both Togo and Fiji through direct coercive measures enacted under a hard PTA with the EU. In the case of Togo, following unsuccessful political consultations, the EC enacted Article 366a - the suspension clause of the Lomé IV Convention-in reaction to violation of democratic and human rights principles enshrined in the PTA, including serious irregularities in the application of political and civil rights. ${ }^{60}$ Cooperation under Lomé was reinstated only after the government demonstrated significant steps had been take toward compliance with reforms identified by the EC, including the establishment of a new electoral code and new elections. ${ }^{61}$ Cooperation was similarly suspended in the case of Fiji after the overthrow of the democratically elected government and the repeal of the constitution. Threatening to impose sanctions and invoking the human rights clause under Cotonou (Article 96), the EC postponed financing of investment projects under the 9th EDF until political reforms were undertaken to secure democracy and respect for human rights. ${ }^{62}$

Evidence also shows that PTAs have at times been influenced by threat of sanction without implementation. Pakistan is one such case. The Pakistani government has long had trade relations with Europe. The EC's generalized system of preferences (GSP) establishes protective labor conditions with Pakistan on the importation of certain industrial and agricultural products. ${ }^{63}$ Respect for worker's rights was established as a condition for tariff preferences. In 1995 the Trades Union Confederation mobilized against the government's use of forced child labor, and the European Parliament requested an immediate investigation of the misconduct. ${ }^{64}$ Although the European Commission deliberated a ban on imports to coerce new policies on child labor, it ultimately did not implement a ban. Rather, the Commission chose to pursue influence through the threat of a ban coupled with

58. See Riedel and Will 1999; and European Commission 1998b.

59. Coercion in Myanmar demonstrates a similar process of influence. In 1996 the human rights clause of the Generalized System of Trade Preferences (GSP) was also successfully applied against the Union of Myanmar for alleged use of forced labor. See Brandtner and Rosas 1999.

60. The Council decision was adopted in December 1998. See European Commission 1998a.

61. See Bulterman 1999; and Fierro 2003.

62. European Commission 2000a.

63. The GSP is a unilateral preferential instrument as compared to bilateral PTAs such as Lomé and Cotonou. There are currently two forms of standards regulated through the GSP, recognized in Regulations $3281 / 94$ and $1256 / 96$. The first is a negative provision: if a beneficiary country fails to provide internationally recognized workers rights, the country may be deprived, unilaterally, of GSP eligibility for selected articles. The second is a positive provision known as the "special incentives arrangements": developing countries can apply for further preferences if they can demonstrate the complete implementation of standards in ILO Conventions combating forced labor and child labor, and protecting the freedom of association, the right to collective bargaining and nondiscrimination in employment. Note that Pakistan is not a member of the special arrangement.

64. European Parliament Resolution, 14 December 1995. 
positive incentives for Pakistan's active participation in the International Labor Organization's (ILOs) program for the eradication of child labor (IPEC). During the proceedings, which continued into 1997, Pakistan introduced national legislation outlawing child labor as a direct response to the investigation, and subsequently supplied the Commission with regular information of the government's efforts to implement the new human rights policies, which remain problematic but are under reform. ${ }^{65}$

Brandtner and Rosas (1999) identify a Commission statement that reveals the Community's strategy in this case:

The overriding objective of the procedure, during which contracts are established with the authorities of the countries concerned, is to bring about progress on the ground by encouraging the countries concerned to pursue a qualitative social development, a process the Community backs up with complementary schemes. Preferences are withdrawn as a last resort, if the first two stages have come to nothing. ${ }^{66}$

Human rights reforms have similarly been initiated in the Comoros Islands and Niger under threat to enact measures supplied by a hard PTA. In both cases, suspension of market access under Lomé was threatened by the EC following military coups leading to human rights violations. Substantial reforms by each government to comply with the EC's demands were initiated and cooperation was conditionally reinstated during consultations in lieu of suspension. ${ }^{67}$

Still other cases offer evidence that some PTAs influence through coercion coupled with persuasion. Slovakia is a strong case. ${ }^{68}$ At the 1993 Copenhagen European Council, the EC adopted a number of political criteria for accession candidates, including "Human Rights and the Protection of Minorities." Article 49 of the Treaty on the European Union established that accession must be approved by unanimous vote of the Council and an absolute majority of the Parliament, with the Opinion of the Commission playing an important role. Early on, the European Commission expressed the opinion that Slovakia did not qualify for accession negotiations, citing the government's failure to fulfill the democratic and human rights

65. Brandtner and Rosas 1999. In a related case, trade preferences under the GSP were suspended with Burma in 1997 because of the existence of forced labor.

66. Ibid., 717. It is during this period that the Commission began negotiations with Pakistan to conclude a Third Generation Cooperation Agreement, containing ever-stronger obligations to protect human rights. In 1999 signature was delayed repeatedly as a direct result of Pakistan's nuclear testing and human rights abuses, while a further set of conditions were imposed for membership. Signature of the new agreement, which is nonpreferential, took place under the new government of President Pervez Musharraf in 2001, but has not yet entered into force. The EC's External Relations is available at 〈http://europa.eu.int/comm/external_relations/pakistan/intro/index.htm〉. Accessed 28 March 2005. Note that in the wake of the terrorist attacks on 11 September 2001 against the United States, the EU granted Pakistan an inclusive package of trade preferences.

67. See European Commission 1999a; and European Commission 1999b.

68. Other related cases of successful coercion toward compliance with human rights norms include the EC's trade policy toward certain countries of the former Yugoslavia. See Brandtner and Rosas 1999. 
elements of the Copenhagen criteria, and in particular, respect for minorities. ${ }^{69}$ Several precise violations were formally articulated over several years, including recommendations for changes in national laws and policies concerning the rights of the political opposition, limitations on the power of the executive, the activities of police and secret service, and repression of Hungarian and Roma minorities. ${ }^{70}$

In the subsequent phases of negotiations, the Commission cites substantial improvements in respect for civil and political rights in Slovakia, including support for civil society organizations and protection of the rights of minorities. ${ }^{71}$ These improvements were required in order to be considered eligible for accession, giving Slovakia's rulers considerable incentives to change their domestic policies. In 1999 the Commission determined that Slovakia had taken the necessary steps to fulfill the basic Copenhagen political criteria, although the report identified further areas of human rights policy for reform. ${ }^{72}$ By 2003 the government had ratified all of the human rights legal instruments under the justice and home affairs acquis, and the Commission was of the opinion that Slovakia was continuing to meet the human rights requirements of accession and taking positive steps toward improvement. ${ }^{73}$

Côte d'Ivoire's trading relationship with the United States demonstrates a similar process of influence through coercion, although influence has been limited and confined to workers' rights in the export sectors. The African Growth and Opportunity Act (AGOA) of 2000, which is an autonomous U.S. trade instrument signed into law as Title 1 of The Trade and Development Act of 2000, provides concrete market incentives for certain African states to liberalize their economies. The agreement aims to increase trade and investment in the region, while pressuring governments through the implementation of hard standards to promote the basic observance of human rights as a fundamental principle of trade, with specific attention to workers' rights. Côte d'Ivoire has been a candidate government since 2000, although the government (brought to power by military coup), was repeatedly denied trade benefits by the U.S. trade representative, "largely because of con-

69. See Bulterman, Hendriks, and Smith 1998; and Nowak 1999. Human rights abuses were also identified in the cases of Bulgaria and Romania, although violations did not technically violate the Copenhagen criteria for suspension of negotiations toward agreement. The Commission, through comprehensive annual evaluations, nevertheless articulated human rights reforms to be undertaken in both countries. See Fierro 2003, 142. Negotiations toward accession have been stopped in the case of Turkey as well, where violations of human rights have long been the primary obstacle to further integration.

70. See European Commission 1997 and 1999c.

71. It is important to remember that negotiations over EU membership represent the best instances of PTA influence. The EU is a PTA in the rare form of an economic union, offering a wide range of benefits that far exceed almost all other forms of preferential trade (such as free trade agreements, customs unions, and common markets). Nevertheless, negotiations over accession to the EU provide a prime example of PTA influence at its best.

72. European Commission 1999c. The central form of coercion in this case was enacted through the suspension of negotiations toward an accession agreement rather than suspension of the existing Europe Agreement, which also contained a hard human rights standard.

73. European Commission 2003. 
cerns related to rule of law, human rights, political pluralism, and economic reform." 74

Although violations of civil and political rights were a serious problem in both rebel and government areas of control, the United States recently granted Côte d'Ivoire membership in exchange for several minor advances toward protection of workers' rights. Specifically, the government agreed to support a protocol initiated by the U.S. Chocolate Manufacturers Association to address forced and hazardous child labor in the cocoa sector, which is one of the largest agricultural sectors and, together with coffee, accounts for three quarters of the country's export earnings. The government also began drafting legislation to conform to ILO conventions, as requested by the U.S. trade representative. ${ }^{75}$ Reforms, although limited, have taken place to gain trade membership. Côte d'Ivoire's exports under the agreement were valued at roughly $\$ 50$ million in 2002, representing 13 percent of the country's total exports to the United States. While the United States used market access to press for reforms of labor rights, the EU opened consultations under Article 366a of Lomé to press for improvements in civil and political rights. The Commission recognizes that progress has been minimal but gradually improving. ${ }^{76}$

These cases show clear instances where an agreement with hard standards influenced a repressive government to improve specific human rights practices after joining. ${ }^{77}$ The cases show various forms of influence across various actors facing different kinds of human rights problems, in different regions of the world. They also show that there is significant variation across hard PTA design, and thus effectiveness in influencing compliance. ${ }^{78}$ It is regrettably difficult, however, to collect evidence from all existing PTAs with hard standards. So many agreements are new, are in the process of being institutionalized, or have yet to take actions based on their human rights standards. Moreover, few agreements offer transparent reporting mechanisms that reveal their human rights actions and most do not yet supply assessments of their influence on standards. The cases selected here thus focus on agreements with Europe or the United States precisely because these PTAs offer some degree of transparency and substantial institutional histories of using standards. Nevertheless, several hard agreements now coordinate trade among states

74. Office of the United States Trade Representative 2001 and 2002, 85.

75. Office of the United States Trade Representative 2003.

76. European Commission 2001a.

77. For more examples, see Hazelzet 2001. In many cases, coercion has taken place during negotiations towards the formation of a hard PTA. Negotiations toward the formation of a Partnership and Cooperation Agreement between the EC and Belarus, for example, were suspended following the 1996 deterioration of human rights and made conditional upon reforms. See Fierro 2003.

78. There are several examples where PTAs with hard standards have failed to bring about compliance with human rights norms, either because the target government has chosen to forgo side payments in exchange for reforms, as in the case of Zimbabwe, or because the supplier lacks the political resolve to effectively coerce, as in the cases of China and Russia. See Miller 2004 for examples. Application of hard standards is selective and merits a separate analysis. 
outside of Europe or North America. There is at present no strong case study evidence to either support or reject the proposition that these PTAs influence members' human rights practices, and further research into these new cases will be crucial in the next few years.

Moreover, human rights conditionality is by no means without its critics. Several lessons have emerged from theses cases that suggest limits to PTA capacity to shape human rights. ${ }^{79}$ PTA influence is almost always limited to "first generation" human rights protecting civil and political liberties and securing freedom from torture and violent repression. ${ }^{80}$ The United States is one of the only countries to prioritize workers' rights over the rights of all people, and in fact, to acknowledge reforms in workers rights while ignoring violations of civil and political rights, as in the case of the Côte D'Ivoire. Implementation of trade coercion measures has historically been selective, while influence is partial and sometimes sectoral. ${ }^{81}$ PTAs are not designed to transform governments from serious repressors into committed protectors, but rather to provide the incentives for small and often incremental changes in some policies. Sometimes this process should fail, as policy implementation requires a high degree of conceptual clarity in an agreement's human rights mandate, as well as the commitment by agreement shareholders that violation will be punished by reducing or ceasing trade agreement benefits. ${ }^{82}$ Failure on the part of member states to enforce the human rights conditions of the contract can effectively reduce the credibility of future threats of enforcement and weaken the organization's ability to tie the hands of local elites to accept human rightsrelated trade practices. ${ }^{83}$

\section{Quantitative Evidence}

To test these theoretical implications more systematically, it is important to consider the domestic political and economic characteristics that are thought to influence repression of human rights. I begin by estimating the following model:

79. See Crawford 1998; and European Commission 2000b and 2000c.

80. Bandtner and Rosas 1999.

81. The United States, for example, routinely dismisses or postpones country petitions under the Generalized System of Preferences for violation of labor rights (OECD 1996), while various member states of the EC have shown clear limitations of political will to enforce negative PTA measures toward several former colonies. King 1999.

82. This article proceeds under the working assumption that hard PTAs supply a positive degree of credible threats and material incentives. However, PTAs may actually vary in their supply of credibility and incentives, suggesting the use of a weighting scheme to sort institutions. Although desirable, such a weighting scheme is hard as a practical matter, and as other scholars of organizations have noted, there is little extant theory to guide the effort (Oneal and Russett 1999). Further research into how PTAs vary in their incentives and credibility would be extremely useful, but is beyond the immediate scope of this article.

83. See European Commission 2000d and 2001b. 


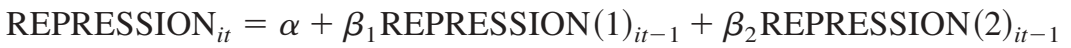

$$
\begin{aligned}
& +\beta_{3} \operatorname{REPRESSION}(3)_{i t-1}+\beta_{4} \operatorname{REPRESSION}(4)_{i t-1} \\
& +\beta_{5} \text { DEMOCRACY }_{i t-1}+\beta_{6} \text { DURABILITY }_{i t-1} \\
& +\beta_{7} \text { DENSITY }_{i t-1}+\beta_{8} \text { TRADE }_{i t-1} \\
& +\beta_{9} \text { INVESTMENT }_{i t-1}+\beta_{10} p c \mathrm{GDP}_{i t-1}+\beta_{11} H R A s_{i t-1}
\end{aligned}
$$

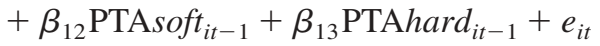

\section{Data}

This study follows an increasing number of human rights scholars in the use of data measuring political terror. The dependent variable, REPRESSION ${ }_{i t}$, offers information about murder, torture, or other cruel, inhuman, or degrading treatment or punishment; prolonged detention without charges; disappearance or clandestine detention; and other flagrant violations of the right to life, liberty, and the security of the person. I draw on two existing data sources. Poe and Tate offer data on 153 governments' reported levels of repression (or political terror) from 1976 to $1993 .{ }^{84}$ Gibney offers repression data from 1980 to 2002 across a different sample of 141 states and territories. ${ }^{85}$ Data were collected in both cases through content analysis of annual human rights reports issued by Amnesty International. I combine information from the two data sets to create repression indicators on a total sample of 176 states over twenty-six years, 1976 to 2001. The observed value of REPRESSION ${ }_{i t}$ is ordinal, ranging across five levels of behavior. ${ }^{86}$

The first set of independent variables, REPRESSION $(1)_{i t-1}, \operatorname{REPRESSION}(2)_{i t-1}$, $\operatorname{REPRESSION}(3)_{i t-1}$, REPRESSION $(4)_{i t-1}$, are binary indicators measuring a state's previous level of repression. They are included in place of the standard lagged dependent variable to account for dependence across the categories of the dependent variable over time. ${ }^{87}$

It is important to control for three independent variables that capture elements of the domestic political context. First, DEMOCRACY ${ }_{i t-1}$ measures Polity IVd regime characteristics, coded by Jaggers and Gurr. The well-known variable takes on

84. For details, see Poe and Tate 1994. Data are available from 〈http://www.psci.unt.edu/ihrsc/ poetate.htm.) Accessed 10 March 2005. My thanks to Steven Poe and his team at the University of North Texas for sharing their data.

85. Data are available from 〈www.unca.edu/politicalscience/faculty-staff/gibney.html $\rangle$. Accessed 10 March 2005. My thanks to Mark Gibney and his team at the university of University of North Carolina-Asheville for sharing their data.

86. Coding rules are described in the Appendix 2.

87. Because REPRESSION ${ }_{\text {it }}$ is treated as a nonlinear dependent variable, it is not appropriate to control for autocorrelation through the standard treatment of REPRESSION $\mathrm{it}_{\mathrm{it}}$ as a lagged linear dependent variable. The inclusion of four dummy variables is a nice alternative to the problem of correlated categories of repression within a state across time. 
TABLE 1. Descriptive statistics and associations, 1972-2002

\begin{tabular}{|c|c|c|c|c|}
\hline \multirow[b]{2}{*}{ Values } & \multicolumn{4}{|c|}{ Dependent variables: Percentage distribution over time } \\
\hline & $\begin{array}{c}\text { REPRESSION }_{i t} \\
(i=176, t=1976-2002)\end{array}$ & \multicolumn{2}{|c|}{$\begin{array}{c}\text { IMPUTE }_{i t} \\
(i=181, t=1976-2002)\end{array}$} & $(i=185, t=1972-2001)$ \\
\hline & & & & 13.31 \\
\hline & & & & 14.46 \\
\hline & & & & 12.12 \\
\hline & & & & 12.51 \\
\hline & & & & 18.85 \\
\hline & & & & 17.04 \\
\hline & & & & 11.72 \\
\hline \multicolumn{2}{|c|}{ Independent variables } & Minimum & Mean & Maximum \\
\hline \multicolumn{2}{|c|}{$\operatorname{REPRESSION}_{i t-1}$} & 1 & 2.47 & 5 \\
\hline \multicolumn{2}{|c|}{ IMPUTE $_{i t-1}$} & 1 & 2.47 & 5 \\
\hline \multicolumn{2}{|c|}{ CIVILLIBERTY $_{i t-1}$} & 1 & 4.07 & 7 \\
\hline \multicolumn{2}{|c|}{ DEMOCRACY $_{i t-1}$} & -10 & 0.19 & 10 \\
\hline \multicolumn{2}{|c|}{$\operatorname{DURABILITY}_{i t-1}$} & 0 & 22.51 & 192 \\
\hline \multicolumn{2}{|c|}{$\operatorname{DENSITY}_{i t-1}$} & 0.20 & 3.76 & 8.55 \\
\hline \multicolumn{2}{|c|}{ TRADE $_{i t-1}$} & 2.43 & 4.30 & 6.11 \\
\hline \multicolumn{2}{|c|}{$\mathrm{FDI}_{i t-1}$} & 2.30 & 2.44 & 3.94 \\
\hline \multicolumn{2}{|c|}{$p c \mathrm{GDP}_{i t-1}$} & 4.45 & 7.53 & 10.87 \\
\hline \multicolumn{2}{|c|}{ TREATY $_{i t-1}$} & 0 & 0.85 & 2 \\
\hline \multirow{2}{*}{\multicolumn{2}{|c|}{$\begin{array}{l}\text { PTAsoft } \\
\text { PT }-1\end{array}$}} & 0 & 0.14 & 1 \\
\hline & & 0 & 0.28 & 1 \\
\hline
\end{tabular}

values ranging from 10 (most democratic) to -10 (most autocratic). ${ }^{88}$ Second, DURABILITY $_{i t-1}$ counts the number of years since a state has undergone a structural regime transition, defined as a movement on the Polity scale of three points or more. Previous research has shown that state level of institutionalized democracy has an important effect on government respect for human rights-democracies are less likely to commit human rights violations than autocracies. ${ }^{89}$ Regime transitions may also affect level of repression inside a state. It is thus important to control for domestic political institutions to isolate the influence of international institutions. Consistent with the literature, I expect the estimates on

88. Jaggers and Gurr construct a democracy index from five primary institutional features. For a detailed explanation of the data, see $\langle$ http://www.cidcm.umd.edu/inscr/polity/ $\rangle$. Accessed 10 March 2005.

89. See Henderson 1991; Poe et al. 1999; and Cingranelli and Richards 1999. 
DEMOCRACY $_{i t-1}$ and DURABILITY ${ }_{i t-1}$ to be negative. Third, DENSITY $i t-1$ measures state population density (per kilometer), collected by the World Bank. Scholars are concerned that population pressure can exacerbate resource scarcity and increase the likelihood that a government will use repression to control civil violence. ${ }^{90}$

It is equally important to control for three independent variables that capture elements of the domestic economy. TRADE ${ }_{i t-1}$ and INVESTMENT ${ }_{i t-1}$ control for the possible effects that international financial and market transactions may have on human rights, independent from the international economic institutions. Past studies provide evidence that global economic flows shape government repression of human rights, either encouraging governments to improve protection of human rights, or promoting repression. ${ }^{91}$ I draw on data from the World Bank in order to measure these flows in the broadest sense possible. TRADE ${ }_{i t-1}$ measures the sum of a state's total exports and imports of goods and services measured as a share of gross domestic product. INVESTMENT it $-1_{1}$ measures the sum of the absolute values of inflows and outflows of foreign direct investment recorded in the balance of payments financial account. ${ }^{92}$ The indicator is calculated as a ratio to gross domestic product (GDP) converted to international dollars using purchasing power parities. $^{93}$

Finally, $p c G D P_{i t-1}$ measures GDP per capita in constant US dollars. Many studies on human rights practices examine the effects of economic development. Mitchell and McCormick proffer the "simple poverty thesis," a commonly accepted view that lack of economic resources creates fertile ground for political conflict, in many cases prompting governments to resort to political repression. ${ }^{94}$ In an advanced economy where people are likely to have fewer grievances, political stability is often achieved more easily, reducing the likelihood of human rights violations. ${ }^{95}$ All three measures are logged in order to reduce the skew of their distributions. I expect the estimate of $p c G D P_{i t-1}$ to be negative.

I analyze the effects of state commitment to HRAs and PTAs by introducing three core variables. In order to test Hypothesis 1, I consider state commitment to implement human rights agreements, HRAs $_{i t-1}$. Specifically, I consider ratification, succession, and accession to two treaties designed to influence political terror and civil rights, and thus directly related to the dependent variable: the International Covenant on Civil and Political Rights and the Convention Against Torture. $\operatorname{HRAs}_{i t-1}$. is an ordinal variable ranging from 0 to 2 , derived from the

90. See Henderson 1993; and Poe and Tate 1994.

91. See Cingranelli and Richards 1999; and Richards et al. 2001.

92. This measure includes equity capital and reinvestment of earnings, as well as other long-term and short-term capital taken into consideration by a variety of human rights scholars.

93. In both cases, I include alternative measures of trade and investment as a check on robustness. See Hafner-Burton forthcoming.

94. Mitchell and McCormick 1988.

95. See Pritchard 1989; and Henderson 1991. 
total number of the two treaties that a state $i$ has ratified into national law in time $t .^{96}$

Next, I consider state commitment to trade through PTAs offering human rights standards. Coding state membership in PTAs is not as straightforward as coding state ratification of human rights law. Of the more than 200 regional agreements today in effect, many states belong to several agreements simultaneously. In contrast to international human rights law where all states in the international system are eligible to join, PTAs also limit potential membership to a core economic region of states. All states are thus not eligible to belong to all agreements, and all PTAs do not incorporate human rights standards. Consequently, I test Hypotheses 2 and 3 using two binary measures of state membership in PTAs with human rights standards. ${ }^{97}$ PTAsoft ${ }_{i t-1}$ measures state membership with PTAs supplying soft standards: state $i$ in year $t$ takes on a value of 1 if that state belongs to any soft PTA. PTAhard it $-1_{1}$ measures state membership with PTAs supplying hard standards: state $i$ in year $t$ takes on a value of 1 if that state belongs to any hard PTA.

I coded each policy outcome using content analysis of all PTA formal contracts, including treaties, protocols, and other forms of amendments. For each agreement, I assigned yearly values measuring membership of all states in the international system, the explicit ${ }^{98}$ adoption of human rights language and principles, and whether the benefits accorded by the contract formally depend on those principles (benefits can be withheld for violation). I then transformed the data into state-years and assigned a single binary value for each outcome. Finally, $\mathrm{e}_{i t}$ is a stochastic error term.

\section{Statistical Results}

Column (1) of Table 2 reports ordered logit estimates of the parameters in equation (1). Although I propose several unidirectional hypotheses, I report two-tailed test statistics for all parameters. State commitments to comply with HRAs and soft PTAs do not systematically lead to decreasing repressive behavior in the fol-

96. In order to control for the potential differences in effect between ratification, on the one hand, and succession and accession, on the other hand, I compute a second coding of this variable, HRAs_rat ${ }_{i t-1}$ that counts only ratifications. In order to control for the possibility that the effects of ratification do not take place immediately, but rather over time, I compute a third coding of this variable, HRAs_years $s_{i t-1}$, that counts cumulative years since ratification of the treaties. I report any discrepancies with the estimates of $\mathrm{HRA}_{i t-1}$ in the footnotes.

97. A state with multiple agreements but minimal human rights standards may be more likely to shirk their human rights commitments associated with membership if they can gain the benefits of trade association through other memberships that do not impose conditionality. I also compute proportions in order to consider a state's commitment to PTAs with human rights standards relative to their overall commitment to PTAs.

98. Explicit here refers to those documents using the word "right" or "rights" to refer to human, worker, women, children, migrant, civil or other rights codified by the United Nations human rights legal regime. I do not include intellectual property rights or other usages of the terms that do not refer to one of the above categories. 
TABLE 2. Estimates of the effects of international human rights agreements and preferential trade agreements on repression, 1972-2002

\begin{tabular}{|c|c|c|c|}
\hline Variables & $\begin{array}{c}(1) \\
\text { REPRESSION }_{i t}\end{array}$ & $\begin{array}{c}(2) \\
\text { IMPUTE }_{i t}\end{array}$ & $\begin{array}{c}(3) \\
\text { CIVILLIBERTY }_{i t}\end{array}$ \\
\hline INVESTMENT $_{\mathrm{it}-1}$ & $\begin{array}{c}-0.633 \\
(0.36)\end{array}$ & $\begin{array}{c}-0.616 \\
(0.35)\end{array}$ & $\begin{array}{c}0.262 \\
(0.27)\end{array}$ \\
\hline TRADE $_{i t-1}$ & $\begin{array}{l}-0.483 * * * \\
(0.13)\end{array}$ & $\begin{array}{l}-0.450 * * * \\
(0.12)\end{array}$ & $\begin{array}{c}0.078 \\
(0.10)\end{array}$ \\
\hline$p c \mathrm{GDP}_{i t-1}$ & $\begin{array}{l}-0.162 * * \\
(0.05)\end{array}$ & $\begin{array}{l}-0.160 * * \\
(0.05)\end{array}$ & $\begin{array}{l}-0.264 * * * \\
(0.05)\end{array}$ \\
\hline $\operatorname{DEMOCRACY}_{i t-1}$ & $\begin{array}{l}-0.031 * * \\
(0.01)\end{array}$ & $\begin{array}{l}-0.028^{* * *} \\
(0.01)\end{array}$ & $\begin{array}{l}-0.080 * * * \\
(0.01)\end{array}$ \\
\hline DURABILITY $_{i t-1}$ & $\begin{array}{c}-0.006^{*} \\
(0.00)\end{array}$ & $\begin{array}{c}-0.007 * \\
(0.00)\end{array}$ & $\begin{array}{c}-0.005 \\
(0.00)\end{array}$ \\
\hline $\operatorname{DENSITY}_{i t-1}$ & $\begin{array}{c}0.091 \\
(0.05)^{*}\end{array}$ & $\begin{array}{l}0.090^{*} \\
(0.04)\end{array}$ & $\begin{array}{r}0.017 \\
(0.03)\end{array}$ \\
\hline HRAS $_{i t-1}$ & $\begin{array}{c}0.082 \\
(0.07)\end{array}$ & $\begin{array}{c}0.078 \\
(0.07)\end{array}$ & $\begin{array}{c}0.029 \\
(0.07)\end{array}$ \\
\hline PTAsoft $_{i t-1}$ & $\begin{array}{r}-0.265 \\
(0.16)\end{array}$ & $\begin{array}{c}-0.210 \\
(0.15)\end{array}$ & $\begin{array}{c}-0.197 \\
(0.14)\end{array}$ \\
\hline $\operatorname{PTA} \operatorname{ard}_{i t-1}$ & $\begin{array}{c}-0.255^{*} \\
(0.12)\end{array}$ & $\begin{array}{c}-0.273^{* *} \\
(0.11)\end{array}$ & $\begin{array}{c}-0.303^{* *} \\
(0.11)\end{array}$ \\
\hline$X^{2}$ & $1033.23^{* * * *}$ & $1054.57 * * *$ & $1273.75 * * *$ \\
\hline $\begin{array}{l}\text { Log likelihood } \\
N\end{array}$ & $\begin{array}{l}-2026.06 \\
2244\end{array}$ & $\begin{array}{l}-2135.31 \\
2359\end{array}$ & $\begin{array}{c}-1594.92 \\
2423\end{array}$ \\
\hline
\end{tabular}

Note: All estimates are ordered logit, unless otherwise specified. The numbers in parentheses are panel-corrected standard errors. All models include binary variables for each level of the dependent variable (excluding the most repressive category), lagged. The estimates are not reported to save space: they are all negative and significant at $\leq .001$.

$* * * \mathrm{p} \leq .001 ; * * \mathrm{p} \leq .01 ; * \mathrm{p} \leq .05$.

lowing year. Quite the contrary, HRAS ${ }_{i t-1}$ and PTAsoft $t_{i t-1}$ have no significant effects on the likelihood of repression. ${ }^{99}$ When PTAs contract hard human rights standards, by contrast, member states are systematically more likely to decrease repression.

I compute predicted probabilities of REPRESSION it to interpret these results. Table 3 displays the probabilities, given Model (1), that a state employing repression in time 1 will employ different levels of REPRESSION in time 2. For example, the first two rows presents the probabilities that a state with a REPRESSION $i t$ level of 5-an extreme abuser-will remain an extreme abuser or reform behaviors (to be a level $4,3,2$, or 1) in the following year. The first of these rows shows probabilities

99. The finding on HRAs is consistent with recent empirical work by Hafner-Burton and Tsustui 2005; and Hathaway 2002. 
TABLE 3. Predicted probabilities of repression across time: Hard preferential trade agreements, 1972-2002

Predicted probability of repression in Time 2

\begin{tabular}{|c|c|c|c|c|c|}
\hline Repression at Time 1 & $\operatorname{Pr}(y=1 \mid x)$ & $\operatorname{Pr}(y=2 \mid x)$ & $\operatorname{Pr}(y=3 \mid x)$ & $\operatorname{Pr}(y=4 \mid x)$ & $\operatorname{Pr}(y=5 \mid x)$ \\
\hline \multicolumn{6}{|l|}{$\operatorname{Pr}(\mathrm{y}=5 \mid \mathrm{x}):$} \\
\hline PTA ard $_{i t}=0$ & 0.00 & 0.01 & 0.08 & 0.45 & 0.47 \\
\hline PTA $\operatorname{ard}_{i t}=1$ & 0.00 & 0.01 & 0.10 & 0.49 & 0.40 \\
\hline \multicolumn{6}{|l|}{$\operatorname{Pr}(y=4 \mid x):$} \\
\hline PTA ard $_{i t}=0$ & 0.00 & 0.05 & 0.39 & 0.46 & 0.09 \\
\hline PTA ard $_{i t}=1$ & 0.00 & 0.07 & 0.44 & 0.42 & 0.07 \\
\hline \multicolumn{6}{|l|}{$\operatorname{Pr}(y=3 \mid x):$} \\
\hline PTA ard $_{i t}=0$ & 0.02 & 0.31 & 0.55 & 0.11 & 0.01 \\
\hline PTA $\operatorname{ard}_{i t}=1$ & 0.02 & 0.36 & 0.51 & 0.09 & 0.01 \\
\hline \multicolumn{6}{|l|}{$\operatorname{Pr}(y=2 \mid x):$} \\
\hline PTA ard $_{i t}=0$ & 0.11 & 0.65 & 0.22 & 0.02 & 0.00 \\
\hline PTA $h a r d_{i t}=1$ & 0.14 & 0.67 & 0.18 & 0.02 & 0.00 \\
\hline
\end{tabular}

Note: The predicted probabilities are computed using the ordered logit estimates in column (1) of Table 2. REPRESSION ranges from most extreme (5) to absent (1). Coding rules are listed in Appendix 2. Confidence intervals for each prediction are calculated in the replication file available at $\langle\mathrm{http}: / /$ www.stanford.edu/ emiliehb/ . Accessed $28 \mathrm{March}$ 2005.

calculated when a state belongs to no hard PTAs, while the second shows probabilities calculated when a state belongs to at least one hard agreement, all else at the mean. ${ }^{100}$

The probabilities show quite simply that states belonging to hard PTAs have a lower probability of repressing human rights than states without memberships. A level 4 abuser, for example, is 6 percent more likely to reduce repression in the following year if they belong to a hard agreement, and 2 percent less likely to backslide into more abuse. Repression, however, is sticky, and changes are partial rather than absolute. States are likely to hold to status quo behaviors over time, and when they do reform, repressive states are most likely to move to the next category of REPRESSION $i t$ (from a 3 to a 2), rather than to skip categories (from a 5 to a 1$)$.

\section{Further Considerations}

It is important to consider the robustness of the dependent variable by considering different samples and sources. To this end, I offer two additional measures of the dependent variable and reestimate ordered logit models in columns (2) and (3) of 
Table 2. IMPUTE $_{i t}$ imputes missing values of REPRESSION ${ }_{i t}$ for 114 state-years during which Amnesty International did not produce annual reports. This variable is a robustness check against possible bias in Amnesty International's selection of state-years to report. Data were imputed for missing years on repression data coded from the U.S. State Department annual reports of political terror and several partisan variables in order to control for possible bias from the State Departmentsuch as UN General Assembly voting agreement with the United States. ${ }^{101}$ IMPUTE $_{i t}$ offers information on 181 states during the period 1976-2002.

CIVILLIBERTY $_{i t}$ offers information about repression of civil rights collected annually by Freedom House. Civil liberties include the freedom of expression, assembly, association, education, and religion, protected by an equitable system of rule of law, as well as freedom from political terror. Each country is assigned a value ranging across seven levels of behavior, from strong protection to extreme repression. The variable offers information from 1972 to 2001, on a total sample of 185 states. ${ }^{102}$ The substantive findings are robust across both alternative measures: hard PTAs encourage better human rights practices, while soft agreements and HRAs do not exert a strong influence on behavior.

Table 4 offers three additional robustness checks. Column (1) tests for a European influence. Only 12 percent of states belonging to a hard PTA do not also belong to trade agreements with the EU, and the best information about the ways in which hard agreements influence human rights comes from EU case studies. It is thus possible that PTA influence is a European phenomenon rather than a global one. States with stronger institutionalized trade ties to the EU may be more likely than states with weak ties or with no ties to be influenced by hard PTAs. The limitations of the statistical data make it impossible to analyze the effects of these agreements past 2002, and several PTAs have adopted some measure of hard standards since this time. However, I control for this possibility to the best extent possible by including a new variable. $\mathrm{EU}_{i t-1}$ measures the degree of trade integration between a state $i$ in year $t$ and the EU, coded by the number of shared PTAs. The findings show that the influence of hard PTAs is not driven by trade integration with the EU alone, although the EU is certainly the largest supplier.

Column (2) controls for fixed-time effects, which do not change the substantive results for hard PTAs. Fixed-time effects are useful because they allow one to consider the possibility that time is driving the result; that a norm of human rights has emerged and developed and spread during the past thirty years that accounts for why states more and more sign contracts with human rights standards and implement better practices. The results, however, show us that the institutional effects

101. The imputed values were tested by randomly eliminating 150 Amnesty scores and then correlating the imputed values with the true values, at a correlation of .91. I thank Erik Voeten for undertaking these imputations and for sharing his data.

102. Data and complete coding information are available from〈http://www.freedomhouse.org/ ratings/index.htm>. Accessed 10 March 2005. 
TABLE 4. Additional Robustness checks: Estimates of the effects of EU trade relations and time effects on repression, 1972-2002

(1)

(2)

(3)

EU trade relations Fixed-time effects Economic leverage

\begin{tabular}{|c|c|c|c|}
\hline INVESTMENT $_{i t-1}$ & $\begin{array}{c}-0.689 \\
(0.40)\end{array}$ & $\begin{array}{c}-0.788^{*} \\
(0.40)\end{array}$ & $\begin{array}{r}-0.611 \\
(0.37)\end{array}$ \\
\hline $\operatorname{TRADE}_{i t-1}$ & $\begin{array}{l}-0.525^{* * * *} \\
(0.15)\end{array}$ & $\begin{array}{c}-0.516^{* * * *} \\
(0.14)\end{array}$ & $\begin{array}{l}-0.505^{* * * *} \\
(0.13)\end{array}$ \\
\hline$p c \mathrm{GDP}_{i t-1}$ & $\begin{array}{c}-0.126^{*} \\
(0.06)\end{array}$ & $\begin{array}{c}-0.142^{*} \\
(0.06)\end{array}$ & $\begin{array}{r}-0.122 \\
(0.07)\end{array}$ \\
\hline DEMOCRACY $_{i t-1}$ & $\begin{array}{l}-0.036^{* * * *} \\
(0.01)\end{array}$ & $\begin{array}{l}-0.034 * * \\
(0.01)\end{array}$ & $\begin{array}{l}-0.031 * * \\
(0.01)\end{array}$ \\
\hline $\operatorname{DURABILITY}_{i t-1}$ & $\begin{array}{l}-0.008 * * \\
(0.00)\end{array}$ & $\begin{array}{c}-0.006 \\
(0.01)^{*}\end{array}$ & $\begin{array}{c}-0.006^{*} \\
(0.00)\end{array}$ \\
\hline $\operatorname{DENSITY}_{i t-1}$ & $\begin{array}{c}0.092 \\
(0.05)\end{array}$ & $\begin{array}{c}0.090 \\
(0.05)\end{array}$ & $\begin{array}{r}0.087 \\
(0.05)\end{array}$ \\
\hline $\operatorname{HRAS}_{i t-1}$ & $\begin{array}{r}-0.007 \\
(0.08)\end{array}$ & $\begin{array}{r}-0.005 \\
(0.09)\end{array}$ & $\begin{array}{r}-0.078 \\
(0.07)\end{array}$ \\
\hline PTAsoft $t_{i t-1}$ & $\begin{array}{c}-0.193 \\
(0.15)\end{array}$ & $\begin{array}{c}-0.292 \\
(0.16)\end{array}$ & $\begin{array}{c}-0.226 \\
(0.15)\end{array}$ \\
\hline PTAhard $_{i t-1}$ & $\begin{array}{c}-0.241^{*} \\
(0.12)\end{array}$ & $\begin{array}{l}-0.345^{* *} \\
(0.12)\end{array}$ & $\begin{array}{r}0.527 \\
(0.66)\end{array}$ \\
\hline $\mathrm{EU}_{i t-1}$ & $\begin{array}{r}-0.015 \\
(0.01)\end{array}$ & & \\
\hline PTAhard $_{i t-1} * \operatorname{DENSITY}_{i t-1}$ & & & $\begin{array}{c}0.079 \\
(0.09)\end{array}$ \\
\hline PTA $\operatorname{ard}_{i t-1} * p c \mathrm{GDP}_{\mathrm{it}-1}$ & & & $\begin{array}{r}-0.148 \\
(0.08)\end{array}$ \\
\hline$X^{2}$ & $1309.86 * * *$ & $1396.24 * * *$ & $1161.89 * * *$ \\
\hline $\begin{array}{l}\text { Log likelihood } \\
N\end{array}$ & $\begin{array}{l}-2123.23 \\
2244\end{array}$ & $\begin{array}{l}-2003.63 \\
2244\end{array}$ & $\begin{array}{l}-2023.97 \\
2244\end{array}$ \\
\hline
\end{tabular}

Note: All estimates are ordered logits. The numbers in parentheses are panel-corrected standard errors. All models include binary variables for each level of the dependent variable (excluding the most repressive category), lagged. The estimates are not reported to save space: they are all negative and significant at $\leq .001$.

$* * * \mathrm{p} \leq .001 ; * * \mathrm{p} \leq .01 ; * \mathrm{p} \leq .05$.

are not simply time-dependent. Controlling for every year in the sample, hard PTAs have the expected effect. ${ }^{103}$

Finally, column (3) considers the issue of economic leverage. PTAs influence because they coerce actors into adopting behaviors they might not otherwise adopt, providing economic incentives to actors that value them. Testing economic leverage directly, however, proves to be a difficult task. As a preliminary step, I include two interaction terms between PTA ard $_{i t-1}$ and the GDP and population variables, under the logic that the gains from integration are likely to be more significant for

103. In order to more systematically address concerns of endogeneity, I calculate two-stage leastsquares estimates assuming PTAhard it $_{\text {as }}$ endogenous. Coefficients remain consistent in sign and significance. 
smaller and poorer nations. ${ }^{104}$ The interaction between hard standards and GDP, surprisingly, is negative. The results, however, are rather hard to interpret because of extremely high collinearity (above 0.95 ) between the interaction variable and hard standards, clearly inflating the standard errors. The interaction with population has no clear or significant effect. Although it is beyond the scope of this article to derive better measures of economic leverage, the issue is of clear importance to research on PTA influence and deserves serious further consideration. ${ }^{105}$

\section{Conclusion}

When do states comply with international rules governing human rights? It has been often accepted that states regularly come to change their human rights behaviors when they are persuaded by international actors and institutions: international institutions can change states' preferences for behavior even when coercive instruments of enforcement are not available. ${ }^{106}$ I do not contend in this article that institutions always fail to influence repression through persuasion, but I do argue that there are strong theoretical reasons to be skeptical that persuasion, alone, is likely to be effective much of the time. There is little evidence to show otherwise, and the failure of international human rights agreements to effectively bring about change in behaviors so much of the time should give us cause to rethink current optimism that HRAs can influence without coercion. Far from being counterproductive, some form of coercion may often be essential to bringing about better practices, although certainly not incompatible with most long-terms strategies of persuasion. ${ }^{107}$ Moreover, PTAs may increasingly provide these instruments of coercion that the human rights regime so clearly lacks.

This argument has three core implications. First, human rights regimes alone rarely create the conditions necessary for state compliance with human rights

104. I would like to thank an anonymous reviewer for this suggestion.

105. I also include a binary variable to control for the effects of war on repression of human rights. In times of warfare, governments tend to be more coercive, defending their authority against internal challenges to the state, often through increasing political terror. See Poe and Tate 1994. They may also face armed opposition groups with preferences for human rights that are unlikely to be coerced by RTAs. $\mathrm{WAR}_{i t-1}$ is a dichotomous variable collected by the Correlates of War Project under David J. Singer and Melvin Small (ICPSR Study 9905). It equals 1 if a country is at war, and zero otherwise. States at war are significantly more likely to repress human rights, although the results for hard PTAs remain negative and significant. I also interact DEMOCRACY ${ }_{i t-1}$ and DURABILITY DEt-1 $_{i t}$ in order to see if the time horizon of institutionalized democracy changes the results. The results for hard PTAs remain consistent.

106. Although influence through coercion is almost always beyond the scope of HRAs, many scholars that remain convinced of HRA influence without hard standards also recognize that coercive instruments can be important tools to enforce better practices, and that human rights advocates frequently employ material incentives to proffer norms of better behavior. See, for example, Keck and Sikkink 1998; and Risse, Ropp, and Sikkink 1999. Others support the general views of Chayes and Chayes 1998 by arguing that coercive enforcement is likely to be unproductive, imposing high costs with little behavioral gain. See note 22 .

107. Strategies of economic coercion can also have persuasive effects overtime, as repeated punitive interactions may contribute to the recognition and domestic internalization of the disputed norm. For a similar argument with respect to unilateral economic sanctions, see Cleveland $2001 \mathrm{~b}$. 
because they are almost always soft, lacking the necessary mechanisms to supply strong incentives and commitment instruments to outweigh defection. Second, material and political rewards are often a more effective (and compatible) incentive structure to support the initial stages of compliance. Third, a growing number of PTAs have become part of a larger set of governing institutions enforcing better human rights practices. These agreements can supply limited human rights mandates and influence some governments to make marginal improvements in certain human rights behaviors; they can enforce the initial stages of compliance that most HRAs cannot.

It could easily be argued that PTAs are not ideal forums for human rights governance; that the WTO would be more effective in enforcing better practices; and that better designed HRAs would solve the problems of compliance. Nothing could be closer to the argument proposed here. International institutions have the greatest influence over state compliance with human rights principles when they offer substantial gains with some kind of coercive incentives, perhaps coupled with strategies of persuasion, to change the costs and benefits of repressive actors' behaviors. If the member states of the WTO could agree on a human rights clause linking the terms of trade to the protection of human rights, it could potentially begin to leverage some influence on world repression, and it could certainly empower human rights advocates fighting for reform.

The WTO today, however, provides no formal guidance with respect to member state compliance with international human rights laws or principles. Attempts to adopt even soft standards protecting workers rights have failed time and time again and they appear unlikely to succeed anytime in the near future. ${ }^{108}$ Most human rights agreements are even further from any sort of institutional reform that could impose more enforceable rules of behavior.

PTAs, then, are certainly not ideal forms of human rights governance and they are not a replacement for human rights laws. They are among the only existing international institutions with some capacity to enforce compliance, and they may prove to be one of the more effective available means of implementing very basic human rights values into practice, although partial and imperfect.

\section{References}

Abbott, Kenneth W, and Duncan Snidal. 2000. Hard and Soft Law in International Governance, International Organization 54 (3):421-56.

108. The adoption of rules designed to protect citizens' rights into trade agreements had limited precedent in the pre-GATT era, although the issue of human rights emerged most forcefully during the Uruguay Round. See Francioni 2001. Several countries sought to reintroduce a narrow set of labor rights into the legal architecture of the organization. Perceiving this initiative as protectionist and imperialist, many countries of the developing world launched a campaign to prevent the incorporation of core labor standards into global trade doctrine. See McCrudden and Davies 2000. These disputes eventually led to the 1996 Singapore compromise declaring that the WTO is not the competent body to redress concerns for members' compliance with international labor laws. The compromise was upheld in Seattle (1999), Doha (2001), and Cancun (2003). 
2001. International 'Standards' and International Governance. Journal of European Public Policy 8 (3):345-70.

Amnesty International. 2003. Annual Report. Available at /http://web.amnesty.org/report2003/indexeng $\rangle$. Accessed 28 March 2005.

Anderson, Craig A. 1989. Causal Reasoning and Belief Perseverance. In Proceedings of the Society for Consumer Psychology, edited by D. W. Schumann, 115-20. Knoxville: University of Tennessee Press.

Austin, John, and Sarah Austin. 1861. The Province of Jurisprudence Determined. 2d ed. London: J. Murray.

Axelrod, Robert M. 1984. The Evolution of Cooperation. New York: Basic Books.

Bossuyt, Marc. 2000. The Bossuyt Report: The Adverse Consequences of Economic Sanctions on the Enjoyment of Human Rights. Working Paper E/CN.4/Sub.2/2000/33. Prepared for submission to the UN Commission on Human Rights, Subcommission on the Promotion and Protection of Human Rights.

Brandtner, Barbara, and Allan Rosas. 1999. Trade Preferences and Human Rights. In The EU and Human Rights, edited by Philip Alston, Mara Bustelo and James Heenan, 699-722. New York: Oxford University Press.

Bulterman, Mielle. 1999. Human Rights Dimensions of the Lomé Convention. Netherlands Quarterly of Human Rights 1:83.

Bulterman, Mielle, Aart Hendriks, and Jacqueline Smith, eds. 1998. To Baehr in Our Minds: Essays on Human Rights From the Heart of the Netherlands. Utrecht: SIM, Netherlands Institute of Human Rights.

Bulterman, Mielle, and Martin Kuijer. 1996. Compliance with Judgments of International Courts. Boston: Martinus Nijhoff.

Chayes, Abram, and Antonia Handler Chayes. 1990. From Law Enforcement to Dispute Settlement: A New Approach to Arms Control Verification and Compliance. International Security 14 (4):147-64.

- 1993. On Compliance. International Organization 47 (2):175-205.

1998. The New Sovereignty: Compliance with International Regulatory Agreements. Cambridge, Mass.: Harvard University Press.

Cingranelli, David L., and David L. Richards. 1999. Respect for Human Rights After the End of the Cold War. Journal of Peace Research 36 (5):511-34.

Cleveland, Sarah H. 2001a. Human Rights Sanctions and the World Trade Organization. In Environment, Human Rights \& International Trade, edited by Francesco Francioni, 199-261. Portland, Ore: Hart.

- 2001b. Norm Internalization and U.S. Economic Sanctions. Yale Journal of International Law $1: 1-102$.

Cottier, Thomas. 2002. Trade and Human Rights: A Relationship to Discover. Journal of International Economic Law 5 (1):111-32.

Crawford, Gordon. 1998. Human Rights and Democracy in EU Development Co-operation: Towards Fair and Equal Treatment. In European Union Development Policy, edited by Marjorie Lister, 13178. London: Macmillan.

Davidson, Scott. 1997. The Inter-American Human Rights System. Brookfield, Vt.: Ashgate Publishing.

De Melo, Jaime, and Arvind Panagariya. 1993. New Dimensions in Regional Integration. New York: Cambridge University Press.

Donnelly, Jack. 1986. International Human Rights: A Regime Analysis. International Organization 40 (3):599-642.

Downs, George W., David M. Rocke, and Peter N. Barsoom. 1996. Is the Good News About Compliance Good News about Cooperation? International Organization 50 (3):379-406.

Drezner, Daniel W. 2003. The Hidden Hand of Economic Coercion. International Organization 57 (3):643-59.

Dulitzky, Ariel E. 1999. Book Review: The Inter-American Human Rights System by Scott Davidson. European Journal of International Law 10 (2):475-77.

Eaton, Jonathan, and Maxim Engers. 1999. Sanctions: Some Simply Analytics. American Economic Review 89 (2):409-14. 
European Commission. 1997. Agenda 2000—Commission Opinion on Slovakia's Application for Membership in the European Union (Doc/97/20). Brussels: European Commission. Available at 〈http:// www.europa.eu.int/comm/enlargement/dwn/opinions/slovakia/sk-op-en.pdf $\rangle$. Accessed 28 March 2005.

. 1998a. Communication from the Commission to the Council "Regarding the Conclusion of Consultations with Togo under Article 366a of the Lomé Convention" (SEC 1956 Final, 25 November, 2). Brussels: European Commission.

. 1998b. Evaluation du Programme d'Action Immédiate de Réhabilitation (November 1998Ref. 951452). Brussels: European Commission.

. 1999a. Commission Proposal for a Council Decision "Concluding Consultations with the Comoros under Article 366 of the Lomé Convention and Taking Appropriate Measures" (COM 695 Final, 16 December). Brussels: European Commission.

. 1999b. Communication from the to the Council "On Conclusion of Consultations with Niger Pursuant to Article 366 of the Lomé Convention and Taking Appropriate Measures" (COM 350 Final, 8 July). Brussels: European Commission.

1999c. Regular Report from the Commission on Slovakia's Progress Towards Accession. Brussels: European Commission. Available at http://www.europa.eu.int/comm/enlargement/ report_10_99/pdf/en/slovakia_en.pdf $\rangle$. Accessed 28 March 2005.

2000a. Communication from the Commission to the Council "On the Opening of Consultations with the Republic of Fiji Islands under Article 366 of the Lomé Conventions" (COM 460 Final, 24 July, 2). Brussels: European Commission.

. 2000b. External Evaluation of Community Aid Concerning Positive Actions in the Field of Human Rights and Democracy in the ACP Countries. Vol. 28, August (SCR F5). Brussels: European Commission.

. 2000c. Follow-Up to the First Summit between Latin America, Caribbean and the European Union (COM 670 Final, 31 October). Brussels: European Commission.

- 2000d. To Prepare the Fourth Meeting of Euro-Mediterranean Foreign Ministers, "Reinvigorating the Barcelona Process" (COM 497 Final, 6 September). Brussels: European Commission.

—_ 2001a. Proposal for a Council Decision "Concluding Consultations with Cote D'Ivoire under Article 96 of the Cotonou Agreement" (COM 290 Final, 28 May). Brussels: European Commission.

- 2001b. The European Union's Role in Promoting Human Rights and Democratisation in Third Countries (COM 252 Final). Brussels: European Commission.

- 2003. Comprehensive Monitoring Report on Slovakia's Preparations for Membership. Brussels: European Commission.

European Council. 2003. EU Annual Report on Human Rights (13449/03 COHOM 29). Brussels: European Council.

Fierro, Elena. 2003. The EU's Approach to Human Rights Conditionality in Practice. The Hague, Netherlands: Martinus Nijhoff.

Finnemore, Martha. 1996. National Interests in International Society, Cornell Studies in Political Economy. Ithaca, N.Y.: Cornell University Press.

Finnemore, Martha, and Kathryn Sikkink. 1998. International Norm Dynamics and Political Change. International Organization 52 (4):887-917.

Francioni, Francesco. 2001. Environment, Human Rights and the Limits of Free Trade. In Environment, Human Rights \& International Trade, edited by F. Francioni, 1-26. Portland, Ore.: Hart.

Franck, Thomas M. 1988. Legitimacy in the International System. American Journal of International Law 82 (4):705-58.

1990. The Power of Legitimacy Among Nations. Oxford: Oxford University Press.

- 1995. Fairness in International Law and Institutions. New York: Clarendon Press.

Frankel, Jeffrey A., Ernesto Stein, and Shang-Jin Wei. 1996. Regional Trading Arrangements: Natural or Supernatural? American Economic Review 86 (2):52-56.

Goodman, Ryan, and Derek Jinks. 2004. How to Influence States: Socialization and International Human Rights Law. Duke Law Journal 54 (3), 2004. 
Grether, Jean-Marie, and Marcelo Olarreaga. 1998. Preferential and Non-Preferential Trade Flows in World Trade. Staff Working Paper ERAD-98-10. Washington, D.C.: World Trade Organization.

Hafner-Burton, Emilie M. 2004. Forum Shopping for Human Rights: Who Chooses Preferential Trade? Paper presented at the workshop on Forum Shopping and Global Governance at the European University Institute, Florence, Italy, 23-24 April. Available at 〈http://www.stanford.edu/ emiliehb $\rangle$. Accessed 28 March 2005.

2005. Right or Robust? The Sensitive Nature of Political Repression in an Era of Globalization. Journal of Peace Research. Available at 〈http://www.stanford.edu/ emiliehb $\rangle$. Accessed 28 March 2005.

Hafner-Burton, Emilie M., and Kiyoteru Tsutsui. 2005. Human Rights in a Globalizing World: The Paradox of Empty Promises. American Journal of Sociology 110 (5):1373-1411. Available at 〈http:// www.stanford.edu/ emiliehb $\rangle$. Accessed 28 March 2005.

Hathaway, Oona A. 2002. Do Human Rights Treaties Make a Difference? Yale Law Journal 111 (8):1935-2042.

Hazelzet, Hadewych A. 2001. Carrots or Sticks? EU and US Reactions to Human Rights Violations (1989-2000). Ph.D. diss., European University Institute, Florence, Italy.

2004. Suspension of Development Co-Operation: An Instrument to Promote Human Rights and Democracy? Centre Européen de Gestion des Politiques de Développement (ECPDM) Discussion Paper. Maastricht, Netherlands: ECPDM.

Helfer, Laurence R., and Anne-Marie Slaughter. 1997. Toward a Theory of Effective Supranational Adjudication. Yale Law Journal 107 (2):273-391.

Helson, Arthur C., and Robert P. DeVecchi. 2000. Human Rights, Humanitarian Intervention \& Sanctions. Council on Foreign Relations Issue Brief. Washington, D.C.: Council on Foreign Relations.

Henderson, Conway W. 1991. Conditions Affecting the Use of Political Repression. Journal of Conflict Resolution 35 (1):120-42.

_. 1993. Population Pressures and Political Repression. Social Science Quarterly 74 (2):323-33.

Henkin, Louis. 1979. How Nations Behave: Law and Foreign Policy. 2d ed. New York: Council on Foreign Relations/Columbia University Press.

Howard, Rhoda, and Jack Donnelly. 1986. Human Dignity, Human Rights, and Political Regimes. American Political Science Review 80 (3):801-18.

Johnston, Alastair Iain. 2001. Treating International Institutions as Social Environments. International Studies Quarterly 45 (4):489-90.

Kahler, Miles, and David A. Lake. 2003. Governance in a Global Economy: Political Authority in Transition. Princeton, N.J.: Princeton University Press.

Keck, Margaret E., and Kathryn Sikkink. 1998. Activists Beyond Borders: Advocacy Networks in International Politics. Ithaca, N.Y.: Cornell University Press.

Keohane, Robert O. 1984. After Hegemony: Cooperation and Discord in the World Political Economy. Princeton, N.J.: Princeton University Press.

King, Toby. 1999. Human Rights in European Foreign Policy: Success or Failure for Post-Modern Diplomacy? European Journal of International Relations 10 (2):313-37.

Kirkpatrick, Jeane. 1979. Dictatorships and Double Standards. Commentary 68 (5):34-45.

Koh, Harold Hongju. 1996-97. Why Do Nations Obey International Law? Yale Law Journal 106 (8):2599-659.

— 1998. How Is International Human Rights Law Enforced? Indiana Law Journal 74 (4):1397-417.

Kratochwil, Friedrich V. 1989. Rules, Norms, and Decisions: On the Conditions of Practical and Legal Reasoning in International Relations and Domestic Affairs. Cambridge: Cambridge University Press.

Krauthammer, Charles. 1989. The Curse of Legalism: International Law? It's Purely Advisory. New Republic 201 (19):44-47.

Lutz, Ellen L., and Kathryn Sikkink. 2000. International Human Rights Law and Practice in Latin America. International Organization 54 (3):633-59. 
Mansfield, Edward D. 1998. The Proliferation of Preferential Trading Agreements. Journal of Conflict Resolution 42 (5):523-43.

Martin, Lisa L. 1992. Coercive Cooperation: Explaining Multilateral Economic Sanctions. Princeton, N.J.: Princeton University Press.

. 1993. The Rational State Choice of Multilateralism. In Multilateralism Matters: The Theory and Praxis of an Institutional Form, edited by John G. Ruggie, 91-122. New York: Columbia University Press.

. 1998. Evasive Maneuvers? Reconsidering Presidential Use of Executive Agreements. In Strategic Politicians, Institutions, and Foreign Policy, edited by Randolph M. Siverson, 51-77. Ann Arbor: University of Michigan Press.

2000. Democratic Commitments: Legislatures and International Cooperation. Princeton, N.J.: Princeton University Press.

Martin, Lisa L., and Kathryn Sikkink. 1993. U.S. Policy and Human Rights in Argentina and Guatemala, 1973-1980. In Double-Edged Diplomacy: International Bargaining and Domestic Politics, edited by Peter Evans, Harold Jacobson, and Robert Putnam, 330-62. Berkeley: University of California Press.

Mattli, Walter. 1999. The Logic of Regional Integration: Europe and Beyond. Cambridge: Cambridge University Press.

McCall Smith, James. 2000. The Politics of Dispute Settlement Design: Explaining Legalism in Regional Trade Pacts. International Organization 54 (1):137-80.

McCrudden, Christopher, and Anne Davies. 2000. A Perspective on Trade and Labour Rights. Journal of International Economic Law 3 (1):43-62.

Mearsheimer, John J. 1994/1995. The False Promise of International Institutions. International Security 19 (3):5-49.

Meyer, John W., John Boli, George M. Thomas, and Francisco O. Ramirez. 1997. World Society and the Nation-State. American Journal of Sociology 103 (1):144-81.

Miller, Vaughne. 2004. The Human Rights Clause in the EU's External Agreements. International Affairs and Defence, House of Commons Library Research Paper 04/33. London: House of Commons. Available at $\langle$ http://66.102.9.104/search?q=cache:BDfad6HTPmkJ:www.parliament.uk/commons/ $\mathrm{lib} / \mathrm{research} / \mathrm{rp2004/rp04-033.pdf}+$ The + Human + Rights + Clause + in + the + EU\%27s + External + Agreements\&hl=en $\rangle$. Accessed 28 March 2005.

Mitchell, Neil, and James McCormick. 1988. Economic and Political Explanations of Human Rights Violations. World Politics 40 (4):476-98.

Mitchell, Ronald B. 1993. Compliance Theory: A Synthesis. Review of European Community and International Environmental Law 2 (4):327-34.

Moravcsik, Andrew. 1995. Explaining International Human Rights Regimes: Liberal Theory and Western Europe. European Journal of International Relations 1 (2):157-89.

- 2000. The Origins of Human Rights Regimes: Democratic Delegation in Postwar Europe. International Organization 54 (2):217-52.

Nowak, Manfred. 1999. Human Rights "Conditionality" in Relation to Entry to, and Full Participation in, the EU. In The EU and Human Rights, edited by Philip Alston, Mara Bustelo, and James Heenan, 687-98. New York: Oxford University Press.

Office of the United States Trade Representative. 2001. Comprehensive Report of the President of the United States, U.S. Trade and Investment Policy Toward Sub-Saharan Africa and Implementation of the African Growth and Opportunity Act. The First of Eight Annual Reports. Washington, D.C.: Government Printing Office.

2002. Comprehensive Report of the President of the United States, U.S. Trade and Investment Policy Toward Sub-Saharan Africa and Implementation of the African Growth and Opportunity Act. The Second of Eight Annual Reports. Washington, D.C.: Government Printing Office.

2003. Comprehensive Report of the President of the United States, U.S. Trade and Investment Policy Toward Sub-Saharan Africa and Implementation of the African Growth and Opportunity Act. The Third of Eight Annual Reports. Washington, D.C.: Government Printing Office. 
Organization for Economic Co-operation and Development (OECD). 1996. Trade, Employment and Labour Standards: A Study of Core Worker's Rights and International Trade (11-12). Paris: OECD.

Oneal, John R., and Bruce M. Russett. 1999. The Kantian Peace-The Pacific Benefits of Democracy, Interdependence, and International Organizations, 1885-1992. World Politics 52 (1):1-37.

Payne, Rodger A. 2001. Persuasion, Frames, and Norm Construction. European Journal of International Relations 7 (1):37-61.

Petersmann, Ernst-Ulrich. 1997. International Trade Law and the GATT/WTO Dispute Settlement System. Boston: Kluwer Law International.

Poe, Steven C., and C. Neal Tate. 1994. Repression of Human Rights to Personal Integrity in the 1980s: A Global Analysis. American Political Science Review 88 (4):853-72.

Poe, Steven, C. Neal Tate, and Linda Camp Keith. 1999. Repression of the Human Right to Personal Integrity Revisited: A Global Cross-National Study Covering the Years 1976-1993. International Studies Quarterly 43 (2):291-313.

Price, Richard. 1998. Reversing the Gun Sights: Transnational Civil Society Targets Land Mines. International Organization 52 (3):613-44.

Pritchard, Kathleen. 1989. Human Rights and Development: Theory and Data. In Human Rights and Development: International Views, edited by D. P. Forsythe, 329-47. London: Macmillan.

Rai, Milan, and Eden, Douglas. 2001. Can We Ever Justify Economic Sanctions? Ecologist (4):24-27.

Richards, David L., Ronald D. Gelleny, and David H. Sacko. 2001. Money with a Mean Streak? Foreign Economic Penetration and Government Respect for Human Rights in Developing Countries. International Studies Quarterly 45 (2):219-39.

Riedel, Eibe, and Martin Will. 1999. Human Rights Clauses in External Agreements of the EC. In The EU and Human Rights, edited by Philip Alston, Mara Bustelo, and James Heenan, 723-54. New York: Oxford University Press.

Risse, Thomas, Stephen C. Ropp, and Kathryn Sikkink, eds. 1999. The Power of Human Rights: International Norms and Domestic Change. Cambridge: Cambridge University Press.

Rosati, Kristen B. 2001. International Human Rights Treaties Can Make a Difference. U.S. Implementation of Article 3 of the United Nations Convention Against Torture. Human Rights 28 (1):14-16.

Ruggie, John Gerard. 1998. Constructing the World Polity: Essays on International Institutionalization. New York: Routledge.

Schwitzgebel, Eric. 1999. Gradual Belief Change in Children. Human Development 42 (1):283-96.

Singer J. David, and Melvin Small. 1994. Correlates of War Project: International and Civil War Data, 1816-1992 (ICPR 9905). Ann Arbor, MI: Inter-University Consortium for Political and Social Research.

Slusher, Morgan, and Craig A. Anderson. 1996. Using Causal Persuasive Arguments to Change Beliefs and Teach New Information: The Mediating Role of Explanation Availability and Evaluation Bias in the Acceptance of Knowledge. Journal of Educational Psychology 88 (1):110-22.

Steiner, Henry J., and Philip Alston. 1996. International Human Rights in Context: Law, Politics, Morals: Text and Materials. Oxford: Clarendon Press.

Winters, L. Alan. 1996. Regionalism Versus Multilateralism. Policy Research Working Paper 1687. Washington, D.C.: World Bank.

Yarbrough, Beth V., and Robert M. Yarbrough. 1997. Dispute Settlement in International Trade: Regionalism and Procedural Coordination. In The Political Economy of Regionalism, New Directions in World Politics, edited by Edward Mansfield and Helen V. Milner, 134-63. New York: Columbia University Press.

Young, Oran R. 1994. International Governance: Protecting the Environment in a Stateless Society. Ithaca, N.Y.: Cornell University Press. 